DEUIFD XLIII / 2016, ss. 101-141.

\title{
İMAM MÂTÜRÎDÎ VE EBUSSUÛD'UN TEFSİRLERİNDE HZ. MERYEM
}

Murat MEMiș*

\author{
ÖZ
}

Hz. Meryem, Hiristiyanlıkta olduğu kadar, Kur'an'ın ona yüklemiş olduğu anlam sebebiyle İslâm dünyasında da önemli bir karakterdir. Onun örnek yaşantısına dair anlatıların Kur'an tefsirlerinde sıklıkla zikredildiğini görmekteyiz. Bu çalışmamızda, dirayet tefsir ekolüne dâhil iki eserde Hz. Meryem ile ilgili yorum ve yaklaşımları karşılaştırmalı olarak ele almaya çalıştık. Bu tefsirlerden birincisi Ebu Mansur el-Mâtürîdî'nin Te'vîlatü'l-Kur'an adlı eseri, diğeri ise Osmanlı Şeyhülislamlarından Hanefi-Mâtürîdî geleneğe mensup Ebussuûd Efendi'nin İssadu Akli's-Selimm adlı tefsiridir. Bu iki tefsir ait oldukları tarih, coğrafya ve kültürel şartlar bakımından birtakım farklılıklar sergilerler. Bu çalışmamız boyunca söz konusu farklilıkların Hz. Meryem'i anlamada ortaya çıkardığı çeşitliliği göstermeye gayret ettik. Her iki tefsirin de, kullandıkları metotlar ve atıfta bulundukları kaynaklar açısından değerlendirilmesi yapılarak $\mathrm{Hz}$. Meryem'in hikâyesini nasıl ele aldıklarını inceledik. Çalışmamızın sonunda, bu çeşitliliğin günümüze sağlayabileceği katkılar üzerine bir değerlendirmede bulunduk.

Anahtar Kelimeler: İmam Mâtürîdî, Ebussuud Efendi, Hz. Meryem

\section{VIRGIN MARY IN COMMENTARIES OF IMAM MATURIDI AND EBUSSUUD}

\section{ABSTRACT}

Virgin Mary, is an important character in the Islamic World, due to the meaning given to her by the Qur'an, as well as in Christianity. Therefore, we see that the narratives of her exemplary life are frequently mentioned in the Qur'an commentaries. In this paper, we try to examine comperatively comments and approaches about Mary, in two rational commentary works. The first of these commentaries, Abu Mansur al-Mâtürîdî's work, Te'vîlâtü'l Koran, and the other one is Ottoman Sheikhulislam Ebussuud's İrshadu Akli al-Salim. These two

\footnotetext{
* Doç. Dr., DEÜ İlahiyat Fakültesi, Kelam Anabilim Dalı Öğretim Üyesi.

Makalenin Hakemlere Gönderiliş Tarihi : 24/03/2016

Makalenin Hakemlerden Geliṣ Tarihi : 23/05/2016
} 
commentaries have some differences in terms of historical, geographical and cultural conditions. In this paper, we tried to show the diversity which caused by the these differences, in understanding Mary. We look at how they are dealing with Mary's story, in terms of sources and methods, they use. At the end of our study, we present an evaluation, if this diversity can provide contributions of today.

Keywords: Imam Maturidi, Ebussuud, Virgin Mary.

\section{Giriş}

Bu makalede, hem Hiristiyanlar hem de Müslümanlar tarafindan dinî önemi olan bir karakter olarak kabul edilen, özellikle de Kur'an-1 Kerîm'in kendisinden yüksek bir takdirle bahsettiği $\mathrm{Hz}$. Meryem'in, Mâtürî̀î ilim geleneğinde kaleme alınan iki önemli tefsirde nasıl dile getirildiğini karşılaştırmalı olarak göstermeye gayret edeceğiz. Bu iki tefsiri seçmemiz ve karşılaştırmalı bir yöntem takip etmemizdeki temel espri, farklı zaman dilimleri ve sosyal şartlarda ortaya konan bu eserlerin Hz. Meryem hakkındaki beyanlarının, bu farklilıklardan ne kadar etkilendiğini tespit edebilmektir. Bu açıdan öncelikle Mâtürîdîlik ve bu geleneğe bağlı olarak kaleme alınan iki tefsirin yazıldığı şartları kısaca dile getirmekte fayda görüyoruz.

Mâtürîdîlik, hicrî IV./miladî X. asırdan itibaren Kelam ilmi alanında ortaya çıkmış ve daha sonraki dönemlerde İslâm düşüncesine önemli katkılar sağlamış olan, Ehl-i Sünnet'in iki büyük ekolünden biridir. Temel prensipleri ve yaklaşımları itibarıyla, İmam-1 Âzam Ebû Hanife'nin görüşleri etrafinda şekillenen Mâtürîdîlik, Mâveraünnehir'den başlayarak özellikle Türklerin ve Hanefillerin yoğun olarak bulunduğu bölgelerde yayılmış ve etkili olmuştur. Bir Kelam ekolü olarak Mâtürîdîlik, bir taraftan Ebû Hanife tarafından dile getirildiği şekliyle Selef akidesîne bağl1lı̆g1, diğer taraftan ise söz konusu akîdeyi rasyonel bir zemine oturtmadaki başarısıyla tebarüz etmektedir.

Ebû Mansûr el-Mâtürîdî, hicrî III./miladî IX. asırda bugün Özbekistan sınırları içerisinde bulunan Semerkand bölgesinde doğmuş ve ömrünü orada geçirmiştir. Dinî ilimler alanında bölgenin önemli eğitim kurumlarından biri olan Cüzcâniye medresesinde öğrenim görmüş ve dönemin meşhur Hanefî âlimlerinden dersler almıştır. Hayatı hakkında çok şey bilinmemekle birlikte onun özellikle sapkın firkalar karşısında 
Ehl-i Sünnet inancını güçlü bir şekilde savunduğu ve Sünnî Kelam ilminin bu bölgedeki kurucusu olduğu bilinmektedir. Bugün itibarıla elimizde bulunan Kitabu't-Tevbid adlı Kelam eseri ile Te'vîlâtü'l-Kur'an isimli tefsiri, onun görüşlerinin daha sonraki asırlar boyunca bilinmesinde ve kabul edilmesinde büyük bir etkiye sahip olmuştur. Bu çalışmamızda kendisinden istifade ettiğimiz tefsiri, dirayet tefsirinin erken dönem en önemli örneklerinden biridir.

Mâtürî̀ı’nin, tefsirinde yöntem ve kaynak olarak, âyetler arasındaki anlam ilişkilerini ön plana çıkarmaya çalıştı̆̆ını ${ }^{1}$, bunun yanı sira Hz. Peygamber'den rivayet edilen hadîslerle ${ }^{2}$ birlikte sahabe ve tabiînden gelen rivayetleri ${ }^{3}$ de dikkate aldığını görmekteyiz. Özellikle Kur'an'da anlatılan önceki peygamberlerin hikâyeleriyle ilgili bölümlerde güvenilir bulduğu bu kaynaklara atıflarda bulunmaktadır. Bunun yanı sıra onun, Kur'an'daki kıraat farklılıkların ${ }^{4}$, kelime ve kavram tahlillerini $i^{5}$ de tefsirinde sıklıkla kullandığını görmekteyiz. ${ }^{6} \mathrm{Bu}$ yöntem ve kaynakların diğer pek çok tefsirde de benimsenip uygulandığını söyleyebiliriz.

Bununla birlikte İmam Mâtürîdî, tefsirde bir kaynak olarak kabul edilen Ehl-i Kitap'tan yapılan nakiller ${ }^{7}$ hakkında oldukça titiz davranır ve

1 Örneğin bkz. Ebû Mansur el-Mâtürîdî, Te'vîlatü'l-Kur'an, tah. Ahmed Vanlıoğlu, İstanbul 2005, 19/17 (IX, 126); 4/171 (IV, 117-120); 66/12 (XV, 279-281) âyetlerinin tefsiri. Te'vîlatü'l-Kur'an'in muhtelif baskıları bulunduğundan, burada kullanacağımız referanslarda öncelikle ilgili sure/âyet numarası, ardından da bizim kullandığımız baskının cilt ve sayfa numarasını parantez içerisinde göstereceğiz.

2 Örneğin bkz. Mâtürîdî, Te’vîlât, $3 / 42$ (II, 300-301); 19/7 (IX, 119); 8/68 (VI, 269270); 5/118 (IV, 378-379) âyetlerinin tefsiri.

3 Örneğin bkz. Mâtürîlî, Te’vîlât, 4/156 (IV, 100); 3/52 (II, 311-313); 28/80 (XI, 8285); 36/14 (XII, 68-69); 19/17 (IX, 126) âyetlerinin tefsiri.

4 Örneğin bkz. Mâtürîdî, Te’vîlât, 19/19 (IX, 127); 66/12 (XV, 279-281) âyetlerinin tefsiri.

5 Örneğin bkz. Mâtürîdî, Te’vîlât, 5/72 (IV, 279-280); 3/46 (II, 304-305); 3/4 (II, 239-240); $3 / 49$ (II, 307-310); 5/110 (IV, 369-371); 23/14 (X, 12-17) âyetlerinin tefsiri.

6 İmam Mâtürîdî’nin tefsir metodu hakkında daha geniş bilgi için bkz. Ahmed Galli, "Mâtürîdî Tefsirinin Baz1 Yönleri”, DEÜ İlabiyat Fakültesi Dergisi, s. 4, ss. 467-480.

7 Günümüze kadar yazılmıs tefsirlerin önemli bir bölümünde Ehl-i Kitab kaynaklı rivayetlerin yer aldığı ve bunların özellikle Kur'an kıssalarının açıklanmasında kullanıldıklarını biliyoruz. Bununla birlikte bu tür rivayetler hakkında tarih içerisinde farklı tavırlar da gelişmiştir. Peygamber Efendimiz (sas) ve Sahabe'nin Ehl-i 
bunların Kur'an tefsirinde kullanılmasını uygun bulmaz. Ona göre Kur'an'ın eski ümmetler hakkındaki beyanları, Hz. Muhammed (sas)'in peygamberliğinin delili konumundadır. Çünkü Hz. Muhammed (sas), kendisine Kur'an nâzil olmadan önce bu tarihî olaylar hakkında bir malumata sahip değildi. Dolayısıyla Kur'an'da bu kıssaların bulunması, ancak Allah'ın ona bunları bildirmesi ile mümkün olmuştur. ${ }^{8}$ Bu yüzden Mâtürîdî, bu kıssaların beyan ettiği hakikatleri gölgeleyecek şekilde onlara Ehl-i Kitap'tan aktarılan bir takım rivayetlerin ve aç1klamaların eklenmesini uygun görmez. Zira o, doğruluğu kesin olarak bilinmeyen bu açıklamaların, tamamı hakikat olan Kur'an beyanlarıyla çelişebileceğini düşünür.

İmam Mâtürîdîye göre söz konusu kıssaların Hz. Muhammed (sas)'in peygamberliği hakkında delil olması, hiçbir yerden öğrenmemiş olduğu halde, bu olayları, Yahudi ve Hiristiyanların da tasdik edeceği şekilde aktarmasından kaynaklanır. Diğer bir ifadeyle Kur'an'da yer alan bu pasajlar, Allah Teâlâ'nın ona bildirmesinden başka türlü açıklanmaya müsait değildir. Ona göre, Peygamber Efendimiz (sas) zamanında yaşayan ve bu pasajları işiten Ehl-i Kitabın, bunlara itiraz etmemiş olmaları bu iddiayı tasdik etmektedir. Diğer taraftan İmam Mâtürîdî, Kur'an'ın kendinden önceki ilahî kitapları tasdik edici' olmasını da bu düşünceye bağlar. ${ }^{10}$ Bununla birlikte İmam Mâtürîdî, daha sonraki y1llarda

Kitab'tan nakil ile ilgili tutumları hakkında daha geniş bilgi için bkz. Abdullah Aydemir, Tefsirde Israiliyyat, İstanbul 1992, ss. 45-63.

8 Te'vîlât, 19/35 (IX, 135-136). Çok yaygin olmamakla birlikte bu anlayışın İmam Mâtürîdî’den öncede benimsendiğini bilmekteyiz. Nitekim İmam Mâtürîdî, bu yaklaşımın Mu’tezilî bir âlim olan Ebû Bekir el-Asamm’a ait olduğunu belirtir; Bkz. Te'vîlât, 19/52 (IX, 145-146).

$9 \quad$ Kur'an'ın önceki ilahî kitapları tasdik edici oluşuyla ilgili şu âyetleri örnek olarak gösterebiliriz: "Onlara, "Allah'ın indirdiğine (Kur'an'a) iman edin" denilince, "Biz. sadece bize indirilene inanmz" deyip, ondan sonra geleni (Kur'an'ı) inkâr ederler. Hâlbuki o, ellerinde bulunan tasdik eden hak bir kitaptır. De ki: "Eğer inanan kimseler idiyseniz, daha önce niçin Allab'in peygamberlerini öldürüyordunu??" (Bakara, 2/91); "Onlara, Allah katından ellerinde bulunan Kitab'ı doğrulayıc bir peygamber gelince, kendilerine kitap verilenlerden bir kısmı, sanki bilmiyorlarmıs gibi Allab'ın Kitab'ın (Tevrat'ı) arkalarna attılar." (Bakara, 2/101).

10 İmam Mâtürîdî’nin dayandığı prensiplerden biri de geçmiş ümmetlere dair hikâyelerin Hz. Peygamber'e Allah tarafından bildirilmiş olmasıdır. Konuyla ilgili şu 
Kur'an kıssalarıyla ilgili Ehl-i Kitap'tan gelen bazı itirazları dikkate almaz. Ayrıca Kur'an'ın eski kitaplarda neyi tasdik ettiğini açıça belirtmeyip, bunların örneklerini de vermez. Onun açısından Peygamber Efendimiz (sas) döneminde bu kıssaların muhatabı olan ve içlerinde söz konusu kitapları iyi bilenlerin de bulunduğu bazı Hıristiyan ve Yahudilerin, bunlar1 gördükten sonra Müslüman olmaları, söz konusu iddiayı delillendirmek bakımından yeterli görülmüştür.

İmam Mâtüridî’nin yaşadığı tarih ve coğrafyanın, onun Hıristiyanlıkla ilgili görüşlerinin mahiyeti açısından önemi vardır. Semerkand ve çevresinde miladî $\mathrm{V}$. asrın sonlarından itibaren az da olsa Nasturî Hıristiyanların varlığına dair bazı bilgiler mevcuttur. ${ }^{11}$ Fakat bu mevcudiyetin, özellikle bölgenin Müslümanlar tarafindan ele geçirilmesinin ardından ilişkileri nasıl etkilediğine dair bilgimiz neredeyse yok gibidir. İmam Mâtürîdî’nin hayatı ile ilgili bilgilerimizin de son derece sınırlı olduğunu da burada hatırlatmalıyız. Bununla birlikte, ele aldığımız konuyla ilgili olmak üzere, İmam Mâtürîdî’nin Tevrat ve İncil'den doğrudan hiçbir alıntı yapmaması, Kur'an'da yer alan tarihî kıssalar hakkında son derece sinırlı malumat vermesinin yanı sıra, içinde bulunduğu tarihî ve bölgesel şartlar da göz önüne alındığında onun

örnekleri hatırlatabiliriz: "(Ey Muhammed!) Bunlar sana vabyettiğimiz gayb baberlerindendir. Meryem'i kim bimayesine alıp koruyacak diye kalemlerini (kurâ için) atarlarken sen yanlarnda değildin. (Bu konuda) tartışirlarken de yanlarnda değildin." (Âl-i İmran, 3/44); "İste bu (kissa), gayb haberlerindendir. Onu sana biz vahiy yolu ile bildiriyoruz. Yoksa onlar tuzak kurarak islerine karar verdikleri zaman sen onlarn yaninda değildin." (Yusuf, 12/102); “(Ey Mubammed!) Mûsâ'ya o emri verdiğimiz zaman sen (vadinin) batı tarafinda değildin. (O olayi) görenlerden de değildin. Fakat biz. (Mûsấdan sonra) birçok nesiller meydana getirdik. Üzerlerinden uzun çağlar geçti. Sen Medyen balke arasında yașıyor değildin, âyetlerimizi onlardan okuyup ögreniyor da değildin. Fakat biz. (bu haberi) göndereniz. Yine biz. (Mûsâ'ya) seslendiğimiz zaman Tûr'un yan tarafinda da degüldin. Fakat Rabbinden bir rabmet olarak, senden önce kendilerine biçbir uyarcı gelmeyen bir kavmi, düsünüp ögü̈t alsmlar diye uyarman için (o haberleri) sana bildiriyoruz:" (Kasas, 28/44-46).

Ayrıca Kur'an-1 Kerîm, hem Hz. Peygamber'in hem de kavminin Kur'an'da geçen bu kıssaları daha önce bilmediğini beyan etmektedir: "Iște bunlar, sana vahyettiğimiz. gayb haberlerindendir. Bundan önce onlar ne sen biliyordun, ne de kavmin. O hâlde sabret. Çünkü (ivi) sonuc, Allah'a karşı gelmekten sakinanlarn olacaktır." (Hud, 11/49).

11 Bkz. Aziz S. Atiya, Doğu Hiristiyanlı̆ğ Taribi, çev. Nurettin Hiçy1lmaz, İstanbul 2005, s. 287-88. Miladî VIII. asrın sonuna doğru, yerel bir Türk kralının isteği üzerine Patrik Timothy tarafindan Semerkand'in bölgedeki faaliyetler için merkez seçildiğ ve buraya bir metropolit atandığ kaydedilmektedir. 
Hiristiyanlarla bir karşılaşma ve diyalog içinde olmadığı sonucuna ulaşmak mümkün görünmektedir. Nitekim onun eserlerinde Hıristiyanlarla ilgili yer alan polemikler, büyük ölçüde Kur'an'ın çizdiği sınırlar çerçevesinde geçmektedir.

Ele aldığımız ikinci Tefsir İşâdu Akli's-Selîm’in yazarı Ebussuûd Efendi ise oldukça farklı bir kültürel ortamda yaşamıştır. Osmanlı Devletinin en ihtişamlı dönemi olan XVI. asırda devletin en üst dinî bürokrasisinin başında 26 yıl görev yapan Ebussuûd Efendi, daha çok tefsir ve fikıh alanlarındaki çalışmalarıyla şöhret kazanmıştır. Üstlendiği devlet görevi itibarıla Osmanlı tebaası arasında bulunan Hiristiyanlarla muarefesinin bulunduğunu tahmin etmek zor değildir. ${ }^{12}$

Tefsirinde kullandığ1 metod ve kaynaklarda İmam Mâtürîdî’ninkilere büyük ölçüde benzerlik arz etmektedir. Onun tefsirini yazarken kendinden önceki tefsir birikiminden, özellikle de Zemahşerî, Fahreddin er-Râzî ve Kadı Beyzâvî'nin eserlerinden ciddi oranda yararlandığını bilmekteyiz. ${ }^{13}$ Bununla birlikte Ebussuûd Efendi'nin tefsirinde, kanonik ve apokrif Incillerde geçen birtakım beyanlara da yer verdiği görülmektedir. Örneğin Hz. İsa'nın çarmıha gerilmesi ile ilgili rivayetleri değerlendirirken, Hz. İsa'nın “içinizden biri, horoz ötmeden önce beni üç kere inkâr edecek" sözlerinin, İncil'deki «bu gece horoz ötmeden sen beni üç kez inkâr edeceksin.» ${ }^{14}$ ifadelerine atıf olduğu aşikârdır. Bununla birlikte Ebussuûd'un ifadeleri ile İncillerin ifadeleri arasındaki farklilıklar, onun atfinın doğrudan İncillerden olmadığ

12 Nitekim onun Osmanlı topraklarındaki Hıristiyan cemaati ile ilgili fetvalarını konu edinen bazı çalışmalar yapılmıştır. Örneğin bkz. Eugina Kermeli, "Ebu’s-Su'ûd'a Göre Kilise Vakıfları ve Osmanlı Hukukundaki Teori ve Pratiğì”, çev. Özgen Özcan, Vakıflar Dergisi, say1: 34 (2010), ss. 165-175; Ertuğrul Düzdağ, Ebussuîd Efendi Fetvalar, İstanbul 1983, ss. 89-107.

13 Ebussuûd Efendi'nin tefsir metodu hakkında daha geniş bilgi için bkz. Abdullah Aydemir, Ebussund Efendi ve Tefsirdeki Metodu, Ankara 1969, ss. 110-156; İsmail Cerrahoğlu, "Ebus-Suûd ve Tefsiri", Diyanet İsleri Başkanlĭğ Dergisi, c. XIII, s. 4, ss. 195-203.

14 Bkz. Markos, 14:30; Luka, 22:34; Yuhanna, 13:38. 
ihtimalini de akla getirmektedir. Nitekim o, bu tür alıntıları, belirli bir kaynağa nispet etmeksizin "denmiştir ki ..." şeklinde aktarır. ${ }^{15}$

Benzer bir șekilde Ebussuûd Efendi, "Onlar tuzak kurdular. Allah da tuqak kurdu. Allah, turak kuranlarn en hayurlısıdır." (Âl-i İmrân, 3/54) âyetini tefsir ederken, Hz. İsa'nın çarmıha gerilmesi ve ardından yeniden görülmesi ile ilgili aktardığı rivayetler de, İncillerdeki bazı beyanlarla benzerlikler arz eder. Rivayete göre çarmıha gerileni görmek üzere $\mathrm{Hz}$. Meryem ve Hz. İsa'nın dua ederek cinlerden arındırdığı bir kadın gelip çarmıhta asılanı gördüklerinde ağlamaya başlarlar. Ardından $\mathrm{Hz}$. İsa gökten inerek onların yanına gelir ve onlara "Ne için ağlıyorsunuz?" diye sorar; onlar da "sana" diye cevap verirler. Bunun üzerine Hz. İsa "Rabbim beni yükseltti ve bana hayırdan başka bir şey isabet ettirmedi. Bu ise (çarmıh) onlara öyle göründü." der. ${ }^{16}$

Diğer örnekleri de göz önüne aldığımızda Ebussuûd Efendi’nin Ehl-i Kitap kaynaklı rivayetlere İmam Mâtürîdî’ye nispetle daha fazla atıfta bulunduğunu ve bunu yaparken metodolojik bir hata görmediğini söylememiz mümkündür. Diğer bir ifadeyle, ona göre Ehl-i Kitap kaynaklarında veya halk arasında aktarilan Hz. Meryem ile ilgili rivayetler, Kur'an'ın anlattığı kıssaya eklenebilir niteliktedir. Hikâyeye eklenen bu ayrıntılar, kıssanın genel amacina ve tarihsel kurgusuna aykırı görülmemiştir.

15 Ebussuûd, İşâadu Akli's-Selîm ilâ Merâaya'l-Kitâbi'l-Kerîm, tah. Abdülkâdir Ahmed 'Atâ, Riyâd 1971; 3: 54 (I, 491). İşâdu Akli's-Selîm'in muhtelif baskılar1 bulunduğundan, burada kullanacağımız referanslarda öncelikle ilgili sûre/âyet numarasını, ardından da bizim kullandığımız baskının cilt ve sayfa numarasını parantez içinde göstereceğiz.

16 İşâad, 3/54 (I, 491). Hz. İsa'nın çarmıhtan sonra yeniden dirilmesi ve görülmesi ile ilgili olarak karşılaştırınız Markos, 16:9 (buraya göre Hz. İsa’yı yeniden dirildikten sonra ilk gören Hz. İsa'nın kendisinden yedi cin çıkarmış olduğu Mecdelli Meryem'dir.); Matta, 28: 9-10 (buraya göre Hz. İsa'y1 yeniden dirildikten sonra ilk görenler, Mecdelli Meryem ve diğer Meryem'dir.); Luka, 24: 8-10; Yuhanna, 20: 11 18. Ebussuûd'un aktardığ1 rivayet, Mecdelli Meryem'in kabrin başında ağliyor olması, Hz. İsa'nın ona neden ağladığını sorması gibi bazı açılardan ise Yuhanna'da yer alan kıssaya daha çok benzemektedir. Bununla birlikte söz konusu hikâye, Hıristiyan kültüründe bilindiği şekliyle bırakılmamış, İslâmî anlayışa göre yeniden dizayn edilmiştir. 


\section{Te’vîlât ve İrşâd Tefsirlerinde Hz. Meryem}

\section{a. Hz. Meryem ve Ailesi}

Kur'an-1 Kerîm'de Hz. Meryem'in ailesi hakkında geniş bir bilgi yer almaz. Babasından İmrân, annesinden ise İmrân'ın karısı olarak bahsedilmektedir. ${ }^{17}$ Ayrıca İmrân'nn ailesinin (soyunun), tıpk1 Hz. Âdem, Hz. Nuh, Hz. İbrahim ve nesli gibi seçkin ve üstün kilındığ1 beyan edilir. ${ }^{18}$ İmam Mâtürîdî tefsirinde Hz. Meryem'in annesi ile ilgili bir bilgi yer almazken Ebussuûd Efendi, bu konuda daha fazla malumat aktarmaktadır. Onun belirttiğine göre Hz. Meryem'in annesi Hanne bint Fâkûzâ'dır. Rivayet edildiğine göre Hanna, yaşı ve kısır bir kadındı. Günlerden bir gün bir ağacın altında gölgelenirken, bir kuşun yavrusunu beslediğini gördü. Kendisinin de bir çocuğunun olmasını temenni etti ve Allah'tan, Beytü'l-Makdis'in hizmetine sunacağı, bir çocuk niyaz etti. Kocası İmrân o hamileyken vefat etti. ${ }^{19}$

Hz. Meryem'in babası İmrân hakkında birtakım tartışmalar söz konusudur. Ebussuûd'un aktardığına göre Hz. Musa ve Hz. Hârun'un babası İmran b. Yeshar ile Hz. Meryem'in babası olan Imrân karıştırılmıştır. Zira İmrân b. Yeshar'ın da Meryem adında bir kızı vardır. Söz konusu âyetlerde kastedilenin onun karısı olduğu zannedilmiştir, ama öyle değildir. Burada bahsi geçen İmrân, Hz. Meryem'in babası İmran bin Mâsân'dır. Hz. Zekeriyya'nın bakımını üstlendiği kişi onun kızıdır. Zira bunlar birbiriyle çağdaştır. ${ }^{20}$

17 Bkz. Âl-i İmrân, 3/35.

18 Bkz. Âl-i İmrân, 3/33-34. Kanonik İncillerde Hz. Meryem’in anne ve babas1 hakkında bir bilgi bulunmamakla birlikte, Thomas İncilinde annesinin ismi Hanna, babasının ismi ise Joachim şeklinde geçmektedir. Bkz. Günay Tümer, Hiristiyanlıkta ve İslâmda Hz: Meryem, Ankara 1996, s. 67. Diğer taraftan Luka İncilinde Hz. İsa'nın soyu Hz. Âdem'e varıncaya kadar tek tek sayılmaktadır. Bu silsilede adı geçen Heli'nin (Luka, 3: 23-38) Hz. Meryem'in ya da nişanlısı Yusufun babası olduğu düşünülmektedir.

19 İşâd, 3/35, (I, 468-469). Bazı Apokrif İncillerde de Hz. Meryem'in annesi Hanne'nin yaşlı ve uzun bir dönemi kısır olarak geçirmiş bir kadın olduğuna dair kayıtlar mevcuttur; bkz. Ömer Faruk Harman, "Meryem”, Dذ், XXIX, 237.

20 İşâd, 3/35 (I, 468-469). Eski Ahit’in ilgili bölümlerinde Hz. Musa’nın babasının adı Amram b. Kohat olarak kaydedilmektedir. Ebussuûd'un kaydettiği Yeshar ismi, 
$\mathrm{Bu}$ karışıklığın oluşmasındaki sebeplerden biri de Kur'an-1 Kerîm'de Hz. Meryem'in "Harun'un kız kardeşi” olarak anılmasıdır. ${ }^{21}$ İmam Mâtürîdî, "Hârun'un kız kardeşi”" ifadesindeki Hârun'un kim olduğu hakkında bazı farklı yorumları dile getirir: Bunlardan ilki, onun Musa (as)'ın kardeşi Harun b. İmrân olduğu yolundadır. Bu konuda bir rivayet bulunduğunu belirten Mâtürîdî, rivayet hakkında bilgi vermez ve aradaki kronolojik farklılığa hiç değinmez. ' İkinci yorum, Hz. Meryem'in aynı babadan bir erkek kardeşi olduğudur. İsmi de Hârun b. İmrân'dır. Üçüncü yorum, Hârun'un o dönemde yaşayan sâlih ve âbid bir insan olduğudur. Hz. Meryem, benzer nitelikleri sebebiyle ona nispet edilmiştir. Dördüncü yorum ise, İsrailoğullarının Hz. Hârun'a duydukları sevgiden dolayı, sâlih olarak gördükleri herkesi onun ismiyle isimlendirdiklerine dair bir bilgidir. Hz. Meryem de, sâlih oluşu sebebiyle ona nispet edilmiştir. ${ }^{22}$ Bununla birlikte Hz. Musa kıssasını yorumladığı bir yerde

yine Eski Ahit'e göre Amram'ın kardeşi Yitshar olmalıdır (bkz. Çıkış, 6:18-20). Bununla birlikte Hz. Meryem'in babasının adı, Luka'daki açık olmayan bir kayıttan başka, Kanonik İncillerde zikredilmezken, akoprif İnciller arasında yer alan Yakup (James) incilinde "Joachim" olarak zikredilir (bkz. Paul Foster, The Non-Canonical Gospels, London 2008, s. 114). Joachim'in babas1 da bazı kaynaklarda "Matthat" (bkz. Anne Cathrine Emmerich, Life of Blessed Virgin Mary, trans., Sir Michael Palairet, Cambridge 1953, s. 17) olarak zikredilmektedir. İmrân b. Mâsân isminin Hz. Meryem'in babası olarak tefsirlerde nasıl yer aldığını tespit edemedik.

21 Meryem, 19/28.

* Âyette kastedilen kişinin Hz. Musa'nın kardeşi Hz. Harun olduğuna dair rivayeti Zemahşerî de kaydeder. Peygamber Efendimiz (sas)'e atfedilen “Harun Nebî̀yi

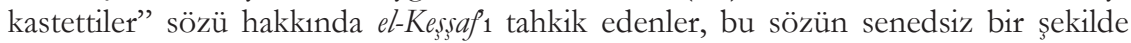
Sa'lebî tarafindan aktarıldığını ve sahih olmadığını belirtirler. Bununla birlikte Necran heyetine elçi olarak gönderilen Muğire b. Şu'be'den sahih bir şekilde Müslim, Nesâî ve Tirmizî̀'de rivayet edilen "size bildirmedim mi, onlar [sâlih kişileri] kendilerinden önceki peygamberlerinin ve sâlihlerinin isimleriyle isimlendiriyorlardı" hadîsini hatırlatırlar (bkz. Zemahşerî, el-Keş̧âf, tah. Şeyh Âdil Ahmed Abdülmevcud, Riyad 1998, IV, 17). Ancak bize göre, sahih olmasa bile, birinci rivayet ile ikincisi arasında herhangi bir tenakuz yoktur. Aksine aynı anlamı ifade etmektedirler. Şu farkla ki, ikinci rivayet âyette yer alan "kıı kardeş" tabirinin mecazî anlamda kullanıldığını daha açı ifade etmektedir. Ancak İmam Mâtürîdî’nin, meselenin izahı sadedinde yukarıda aktarılan dördüncü yorum dikkate alındığında, birinci rivayeti mecazî olarak değerlendirmediği anlaşılmaktadır. Diğer taraftan, ikinci rivayet, bu polemiğin henüz Hz. Peygamber (sas)'in hayatında ortaya çıktığını; problemin ve çözümünün Müslümanlar tarafindan bilindiğini göstermektedir.

22 Te'vîlât, 19/28 (IX, 133). 
İmam Mâtürîdî, Kârun'un Hz. Musa ile olan yakınlığını ifade etmek üzere, onun amcasinın oğlu ve kız kardeşi Meryem’in kocası, yani damatları olduğunu zikreder (Kasas, 28/76). ${ }^{23}$ Ancak İmam Mâtürîdî, yukarıda aktardığımız görüşleri beyan ederken bunların tarihsel gerçeklikleriyle ilgili bir değerlendirmede bulunmaz. Öyle görünüyor ki, onun açısından önemli olan, birincisi hariç bu görüşlerin, Hiristiyanlar tarafindan yapılan Hz. Meryem'in ailevî durumuyla ilgili itirazlara cevap niteliği taşıyor olmasıdır. Ancak yine de o, Müslümanlarla Hiristiyanlar arasındaki böyle bir polemiğin varlığından bahsetmez. Diğer taraftan birinci görüşte Hz. İsa'nın annesi olan Meryem ile Hz. Musa'nın kız kardeşi Meryem'in iki ayrı şahıs olmadıklarına dair bir ima mevcuttur. İmam Mâtürîdî bunun böyle olmadığına dair bir izahta bulunmaz. Dolayısıyla onun bu konudaki yaklaşımı, Hıristiyanlar tarafindan Kur'an'a yöneltilen bir itirazı açık bir şekilde cevaplamaktan uzak görünmektedir.

Ebussuûd Efendi'nin konuyla ilgili tespitleri de benzerlik arz etmektedir. Ona göre Hz. Meryem'i kınayanların Hârun ile kastettikleri Hz. Harun (as)'dır. Zira Hz. Meryem, kardeşlik mertebesinde Hz. Harun'la birlikte olanların ardindaydı. Ayrica Hz. Meryem'in Hz. Harun'un neslinden geldiği ve aralarına bin sene olduğu da söylenmiştir. Bir başka görüşe göre de, söz konusu Harun, onların zamanında yaşayan iyi bir adamdı ya da Hz. Meryem'i kendisine benzettikleri kötü bir adamdı. ${ }^{24} \mathrm{Bu}$ açıklamalara göre Ebussuûd'un aktardığ görüşlerde $\mathrm{Hz}$. Harun ile $\mathrm{Hz}$. Meryem arasındaki tarihsel farklılığ1 dikkate aldığ1 görülmektedir. İki tefsirde baskın olarak öne çıkan görüss ise, iffeti ve adanmışlı̆̆1 sebebiyle Hz. Meryem'in Hz. Harun'a nispet edilmiş olmasıdır. Dolayısıyla Hz. Harun'un babası İmrân ile Hz. Meryem'in babası olan İmrân farklı kişilerdir. İmam Mâtürîdî, İmrân'ın $\mathrm{Hz}$. Davud'un soyundan geldiğine dair bir rivayete de yer verir. ${ }^{25}$

Kur'an-1 Kerîm'de Hz. Meryem ile ilişkisi olan diğer karakterler, Hz. Zekeriyya (as) ve ailesidir. Ebussuûd Efendi'nin aktardığına göre $\mathrm{Hz}$. Zekeriyya (as), İmrân'ın karısı Hanna'nın kız kardeşi ve Hz. Yahya'nın annesi olan Îşấ ile evlenmişti. Dolayısıyla Hz. Peygamber (sas)'in Hz. İsa

\footnotetext{
23 Te'vîlât, 28/76 (XI, 76-79).

24 İșâd, 19/28 (III, 580).

25 Te'vilât, $3 / 36$ (II, 292-293).
} 
ve Hz. Yahya'nın teyze çocukları olduğu şeklindeki beyanı, teyzesinin kızı için de kullanılabilir. Diğer bir açıklama ise, Îşâ’nın anne tarafindan Hanna ile, baba tarafindan da Hz. Meryem ile kardeş olmasıdır. ${ }^{26}$ Ebussuûd Efendi’ye göre Hz. Meryem ile Hz. Zekeriyya ve onların hikâyeleri arasında mükemmel bir bağ bulunmaktadır. $\mathrm{Bu}$ sebeple Kur'an'da Hz. Meryem'in kıssası Hz. Zekeriyya'nın hikâyesinden hemen sonra zikredilmekte ve aralarındaki benzerlikler dikkatlere sunulmaktadır. ${ }^{27} \mathrm{~Hz}$. Meryem ile Hz. Harun arasında salahiyet bakımından bir yakınlık kurulması görüşü, aslında Kitab-1 Mukaddes açısından uzak bir ihtimal değildir. Nitekim benzer bir şekilde, Hz. Meryem'in teyzesi, Hz. Zekeriyya'nın hanımı Elisabet, İncil'de 'Harun'un kızlarından" şeklinde tanıtılmaktadır. ${ }^{28}$

\section{b. Hz. Meryem'in Doğumu ve Yetişmesi}

Kur'an-1 Kerîm Hz. Meryem'den Allah'a adanmış bir kişi olarak bahseder. Bu adanmışlık onun doğumu ile başlamakta ve bir ömür boyu sürmektedir. Annesi ona hamile kaldığında, doğacak çocuğunun sadece Allah'ın hizmetinde olmasını diler ve söz verir. Bunu yaparken aklından bir erkek çocuk geçmektedir. Meryem'i dünyaya getirdiğinde ise, her ne kadar umduğunun bu olmadığını düşünse de, adağından vazgeçmez ve Allah Teâlâ'dan onu ve soyunu korumasını talep eder. ${ }^{29}$

İmam Mâtürîdî, Hz. Meryem'i doğurduğunda annesinin üzüntüsünü, o dönemde Allah'ın dinine hizmetin bir erkek işi olarak görülmesiyle ilişkilendirir. Dolayısıyla bir kız çocuğu bu iş için uygun değildir. Ayrıca ona göre, annenin duası, erkek neslinin de kadınlar üzerinden devam ettiğine delildir. Zira Hz. Meryem'in Hz. İsa'dan başka soyu yoktur. ${ }^{30}$

Annesinin endişesine rağmen Cenab-1 Allah, Hz. Meryem'i en güzel şekilde kabul ettiğini buyurmaktadır: "Bunun üzerine Rabbi onu güzel bir şekilde kabul buyurdu ve onu güzel bir şekilde yetiștirdi. Zekeriyya'yn da onun

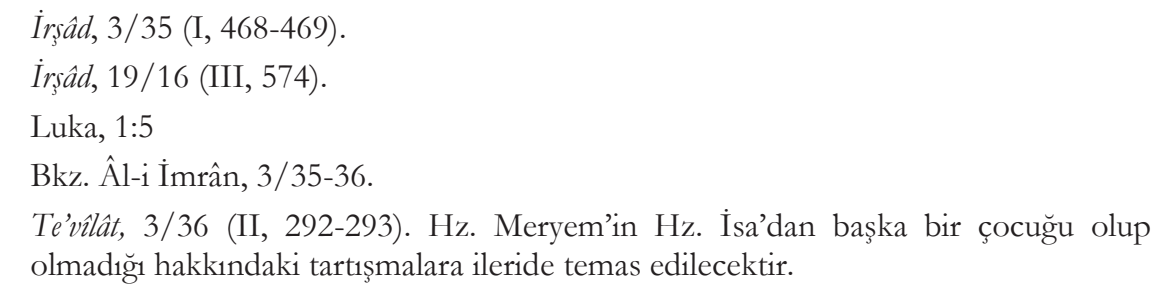


bakimuyla görevlendirdi..." (Âl-i İmran, 3/37). İmam Mâtürîdî’ye göre Allah Teâlâ'nın bu adağı kabul etmesi iki şekilde anlaşılmaya müsaittir: Öncelikle Allah Teâlâ, Hz. Meryem'in annesinin duasını kabul etmiş, onu ve soyunu şeytanın kötülüklerinden korumuştur. İkinci yorum ise, annesinin adağına uygun bir șekilde, Hz. Meryem'in Allah'ın dinine hizmete uygun bir hale getirilmiş olmasıdır. Âyet-i kerîmede geçen, Hz. Meryem'in "en güzel şekilde yetiștirilme" ifadesini ise, şeytanın ona ilişmesinin engellenmesi ve Allah tarafindan en güzel şekilde terbiye edilmesi şeklinde yorumlar. Bu durum aynı zamanda Hz. Meryem'e yapılan lütufla ilişkilendirilmektedir. Zira âyetin devamında $\mathrm{Hz}$. Zekeriyya'nın mâbedde bulunan $\mathrm{Hz}$. Meryem'in yanına uğradığı her seferinde bir takım yiyecekler bulması, İmam Mâtürîlî’ye göre, Hz. Meryem'in, herhangi birinin değil Allah'ın himayesinde olduğunu göstermektedir. Öyle ki, yaz mevsiminde k1ş, kış mevsiminde ise yaz yiyeceklerinin bulunması $\mathrm{Hz}$. Zekeriyya'yı bile hayrete düşürmüştür. ${ }^{31}$

\section{Hz. Meryem'in Mabede Teslimi ve Hz. Zekeriyya}

Ebussuûd Efendi, Hz. Meryem'in doğumundan sonra mâbede teslim edilmesiyle ilgili bir takım rivayetler aktarır. Buna göre, Hanna, Hz. Meryem'i doğurduktan sonra onu bir hırkaya sararak Beytü'l-Makdis'e götürdü; Hz. Harun'un soyundan gelen hahamların önüne koydu ve şöyle dedi: Bu adağa dikkat edin! Bunun üzerine onlar, onun hakkında yarışa tutuştular, çünkü o, önderlerinin kızı idi. Benî Mâsân, İsrailoğulları ve krallarının reisleri idiler. Ayrıca onların, Hz. Meryem ve Hz. İsa hakkındaki durumu kendi ilahî kitaplarında gördükleri de söylenmektedir.

Hz. Zekeriyya "Buna en fazla hak sahibi benim, zira onun teyzesi benim yanımdadır" diyerek öne çıktı. Fakat diğerleri kurâdan başkasına razı olmadılar. Bu grup 27 kişi idi. Nehre gittiler, kalemlerini oraya attılar ve Hz. Zekeriyya'nın kalemi su üstünde kaldı, diğerleri battı. Bunun üzerine bakımını o üstlendi. Bakım ile kastedilen, Hz. Zekeriyya'nın onun

31 Te'vîlât, $3 / 36$ (II, 292-293); ayrica bkz. Te'vîlât, 19/25 (IX, 131).

* Yakup İncil'ine göre Hz. Meryem’in mabede teslimi üç yaşında gerçekleşmiştir, bkz. Yakup İncili, VII:2, (Ekrem Sarıkçıŏlu, Diğer İnciller (Apokrif Inciller), Isparta 2005, içinde s. 53). 
menfaatlerini korumas1, işlerini görmesidir. Diğer taraftan $\mathrm{Hz}$. Zekeriyya'nın kurada kazanması Allah'ın takdiridir. ${ }^{32}$

Bahsi geçen kura olayı hakkında Kur'an-1 Kerîm'de şöyle buyrulmaktadır: "(Ey Mubammed!) Bunlar sana vahyettiğimiz gayb baberlerindendir. Meryem'i kim bimayesine alp koruyacak diye kalemlerini (kurâ için) atarlarken sen yanlarnda değildin. (Bu konuda) tartısırlarken de yanlarmda değildin" (Âl-i İmrân, 3/44). Ebussuûd Efendi, Hz. Meryem'in bakımının üstlenilmesinin ne kadar önemli bir olay olduğunu göstermek üzere, atılan kalemlerin, sıradan kalemler olmayıp Tevrat yazımında kullanıldığına dair bir görüş aktarır. ${ }^{33}$

Kur'an-1 Kerîm Hz. Meryem'in bakımı için kurâ çekiminden bahsetmekle birlikte, bunun ne zaman gerçekleştiği hakkında bilgi vermez. Yakup İncili bu olayın, Hz. Meryem'in mabedden ayrilması sırasında olduğunu kaydederler. Anlatıldığına göre Hz. Meryem oniki yaşına bastığında mabedden ayrilması gerektiğine karar verilmiş ve $\mathrm{Hz}$. Zekeriyya'nın önderlik ettiği ve bir mucizenin gerçekleştiği bir kurâ işlemi yapılmıştır. Bunun sonucunda Hz. Meryem'in bakımını yaşlı, dul ve çocukları olan Yusuf üstlenmiştir. ${ }^{34}$ Yakup İncili'ndeki anlatılardan anlaşıldığına göre, Hz. Meryem'in mabed döneminde bakımını o dönem Başrahip olan Hz. Zekeriyya görmektedir. Kur'an-1 Kerîm'in ilgili yerlerdeki beyanlarına bakıldığında, söz konusu kurânın Hz. Meryem'in mâbedden ayrılması döneminde olduğunu söylemek daha makul görünmektedir. Zira bu olay, Hz. Zekeriyya'nın bir oğul, Hz. Meryem'in de Hz. İsa ile müjdelenmesi beyanları arasında zikredilmektedir. Ayrıca kurâda Hz. Zekeriyyâ'nın kazandığına dair bir bilgi Kur'an-1 Kerîm'de mevcut değildir. Hz. Zekeriyyâ'nın Hz. Meryem’in bakımını üstlenmesi, onun mabede ilk getirilmesi olayıyla ilgilidir. Zira Hz. Zekeriyya, o sırada mâbedin en yetkili kişisidir. Ebussuud Efendi’nin meseleyi bu şekilde değerlendirmesinin sebebi, muhtemelen, söz konusu âyette yer alan "eyyuhum yekfulu" (bakımını kim üstlenecek) (3/44) ibaresi ile yedi âyet öncesinde geçen "keffelehâ Zekeriyya" (Zekeriyya'yı onun bakımıyla görevlendirdi) (3/37) ibaresinde aynı kökten türeyen fiilin kullanılmasına bağlı olarak iki olayı ilişkilendirmesi olabilir.

\footnotetext{
İşâd, 3/37 (I, 471-472).

İşâd, $3 / 44$ (I, 481).

34 Bkz. Yakup İncili, VIII:1-3, IX:1-3, (Sarıkçığlu, age, s. 53-54).
} 
Mâbede teslim edilen Hz. Meryem'in bakımı Hz. Zekeriyya tarafindan üstlenilmiştir. Ebussuûd Efendi'nin aktardığına göre $\mathrm{Hz}$. Zekeriyya onun için mabedde bir mihrab, yani oda inşa etmişti ve emniyet içinde onun yanına giderdi. Denir ki, mihrab, meclislerin en şereflisi ve önde olanıdır; sanki Hz. Meryem, Beytü'l-Makdis'teki en şerefli yere konulmuştu. Rivayet edildiğine göre, bu yere $\mathrm{Hz}$. Zekeriyya'dan başka kimse giremezdi, çıtıtıtan sonra da arkasından yedi kap1 kilitlenirdi. ${ }^{35}$

Kur'an-1 Kerîm Hz. Meryem'in mâbedde geçirdiği günlerde ortaya çıkan bir takım olağanüstü olaylardan bahseder: “...Zekerriya, onun bulunduğu bölmeye her girișinde yannda bir yiyecek bulurdu. "Meryem! Bu sana nereden geldi?" derdi. O da "Bu, Allah katndan" diye cevap verirdi. Zira Allah, dilediğine hesapsız rı̨̨ verir" (Âl-i İmran, 3/37). Ebussuûd Efendi bu âyeti tefsir ederken, Hz. Meryem'in yanında bulunan yiyeceklerin alısılmışın dışında türler olduğunu, zira bu rızıkların ona cennetten indirildiğini kaydeder. Nitekim yaz mevsiminde kış meyveleri, kış mevsiminde de yaz meyveleri bulunuyordu. Yine Ebussuûd, Hz. Meryem'in Allah tarafindan doğrudan rızıklandırıldığını göstermek adına onun hiç kimse tarafından emzirilmediğini de kaydeder. ${ }^{36}$ Ona göre bu tür olaylar, evliyaların keramet göstermesinin imkânına bir delil teşkil etmektedir. Kerâmeti inkâr edenler, bu olayı, Hz. İsa'nın risâletine delil olmak üzere irhas türünden bir harikulade olarak kabul etmişlerdir. Bunun $\mathrm{Hz}$. Zekeriyya'nın bir mucizesi olması ise, onun bu konuda tavr1, yani şaşkınlığını izhar etmesi sebebiyle uygun görünmemektedir. ${ }^{37}$

Ebussuûd Efendi bu âyetle ilgili olarak Hz. Muhammed (sas) ile ilgili bir rivayet aktarır. Buna göre, Hz. Fâtıma (ra), bir gün Peygamber Efendimiz (sas)'e iki parça ekmek ve biraz et ikram etmişti. O (sas) da bunları önce ona geri verdi ve ardından "haydi kızım onları şimdi getir" dedi. Tabak açıldığında, onun ekmek ve etle dolu olduğunu gördüler. Hz. Peygamber (sas) “bu sana neredendir?” (Âl-i İmran, 3/37) diye sordu. Hz.

\footnotetext{
35 İşâd, 3/37 (I, 471-472).

36 İrşâd, $3 / 37$ (I, 472-473). Bazı Apokrif İncillerde, mabede kaldığı dönem boyunca Hz. Meryem'e her gün bir melek tarafindan yiyecek getirildiğine dair kayıtlar vardır; bkz. Ömer Faruk Harman, "Meryem”, DIA, XXIX, 237.

37 İşâd, 3/37 (I, 473).
} 
Fâtıma da "Bu, Allab katındandır; sü̈hesiz. Allah dilediğini hesapsız̨ca ræ̨lklandrrr" (Âl-i İmran, 3/37) diye cevap verdi. Bunun üzerine Hz. Peygamber "Seni İsrailoğullarının hanım efendisine (seyyide) benzer kılan Allah'a hamdolsun" buyurdu. Ardından Hz. Ali, Hasan, Hüseyin ve bütün ehl-i beyt geldiler, yediler, doydular. Yemek ise olduğu gibi kaldı, azalmadı. Onu da komşularına dağıttılar. ${ }^{38}$ Bu rivayete göre Peygamber Efendimiz kendi mucizesi ile Hz. Meryem'in kerameti arasında, Kur'an-1 Kerîm'e atıfta bulunarak bir ilişki kurmaktadır.

Ebussuûd'un aktardığına göre, Hz. Zekeriyya Hz. Meryem'in yukarıda aktarılan kerametini Allah katındaki konumunu gördükten sonra, "Orada Zekeriya Rabbine dua etti: "Rabbim! Bana katundan temiz, bir nesil bahşet. Sü̈phesiz. sen duay hakkkyla işitensin" dedi” (Âl-i İmran, 3/38) âyetinde buyrulduğu üzere, çocuğu olması için Allah'a dua etmiştir. Zira Hz. Zekeriyya'nın karısı da, Hz. Meryem'in annesi gibi yaşlı ve kısır bir kadind $1 .{ }^{39}$

\section{Meryem'in anlamı}

Ebussuûd Efendi, Meryem isminin ne anlama geldiğine dair bazı bilgiler sunar. Ona göre Meryem onların dilinde "ibadet eden" (âbide) anlamına gelmektedir. Kurtubî’den aktardığı başka bir görüşe göre ise, bu isim "Rabbin hizmetkârı" demektir. Ona bu ismin verilmesi, her ne kadar erkek olmasa da, annesinin onu adamaktan dönmemesini göstermektedir. Ayrıca, her ne kadar erkek olmadığı için, Beytu'l-Makdis'in korunması hizmeti açısından uygun değilse de, orada ibadet edenlerden olması içindir. ${ }^{40}$

İmam Mâtürîdî de, "Rabbinin adın an ve bütün benliğinle O'na yönel" (Müzzemmil: 73/8) âyetinin tefsirinde dünya nimetleri ile ilişkisini

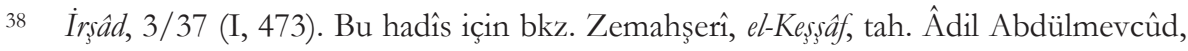
Riyad 1998, I, 554. Keş̧âfin hadislerini tahric eden Cemalüddin ez-Zeylâî, bu hadîsin Ebû Ya'la el-Mevsîlî'nin Müsned adlı eserinde yer aldığını belirtir. Bkz. Cemalüddin Zeylaî̀, Tahricu'l-Ehâdîs, Riyad 1414, I, 184. Ancak biz söz konusu rivayeti, hadîs kaynaklarında bulamadık.

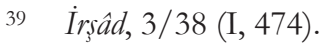

40 İşâd, 3/36 (I, 471). Hiristiyan kaynaklarda "Meryem" isminin daha önce Hz. Musa'nın kardeşi için kullanıldığı kaydedilmekle birlikte, tam olarak nereden türediği anlamının ne olduğu konusunda fikir birliğine varılamamıştır. Bkz. Ömer Faruk Harman, "Meryem”, DIA, XXIX, 236. 
kesmesi, âhiret düşüncesine yönelmesi ve kendini bu yöne adamas1 sebebiyle Hz. Meryem'e "Betül” ismi verildiğini kaydeder. ${ }^{41}$

\section{c. Hz. Meryem'in Üstün Ahlakî Konumu}

Kur'an-1 Kerîm, Hz. Meryem'den bahsettiği bölümlerde onunla ilgili bazı üstün ahlakî nitelikleri dile getirir. Te'vîlât ve İşâd da da bu niteliklerin açılanmasına yer verilmektedir.

İmam Mâtürîdî, "Meryem oğlu Mesih, sadece bir peygamberdir. Ondan önce de nice peygamberler geldi geçti. Onun annesi de dosdoğru (sıddîka) bir kadındır..." (Mâide, 5/75) âyetinde Hz. Meryem için kullanılan "sıddîka" tabiri hakkında şunları söyler: Hz. Meryem bütün kirlerden temizlenmiş düzgün işlerde bulunan saliha bir kadındır. Ayrıca ona göre bu tabir ile Kur'an Hz. Meryem'i, peygamberlere benzetmektedir. Zira Cebrail (as) ona gelip Hz. İsa'y1 müjdelediğinde, Hz. Meryem meleği, diğer peygamberlerin tasdik ettiği gibi tasdik etmiştir. Oysa diğer insanlar, melekleri, ancak peygamberlerin kendilerine verdikleri haber üzerine tasdik edebilirler. Hz. Meryem onu, bizzat tasdik etmiştir. Diğer bir yoruma göre ise, bu tabir onun mümin olduğunu ifade etmektedir. Zira bütün müminler doğru sözlü olmaları hasebiyle "sıddîk" unvanını taşımaktadırlar. ${ }^{42}$

Kur'an-1 Kerîm, Hz. Meryem'in korunmuş olduğuna da değinir. Ebussuûd Efendi, "Onu ve soyunu kovulmuss seytandan senin korumana bırakıyorum” (Âl-i İmran, 3/36) âyetinin tefsirini yaparken şu hadîs-i şerîfi zikreder: "Yeni doğan hiçbir çocuk yoktur ki şeytan, ona doğumu esnasında dokunmuş olmasın. Çocuk şeytanın dokunmasından dolayı ağlar. Meryem ve oğlu ise bundan müstesnâdır." ${ }^{\text {43 }} \mathrm{Bu}$ da şu anlama gelir: Şeytan her çocuğu, kendisinden müteessir olması maksadıyla yoldan

41 Te’vîlât, 73/8 (XVI, 199-201). Betül ismi Arapça'da, dünya ile ilişkisini kesen, kendisini Allah'a adayan, iffetini koruyan, bakire vb. anlamlara gelmektedir.

42 Te'vilât, 5:75 (IV, 281-283).

43 Buhârî, el-Câmiu's-Sahih, tah. Muhammed Zehîr b. Nâsır, Dâru Tavki'n-Necât, 1422, hadîs no: 3431, (IV, 164); Müslim, el-Câmin's-Sahih, Dâru'l-Cîl, Beyrut trs., hadîs no: 6284 (VII, 97); Ahmed b. Hanbel, Müsned, tah. Şuayb el-Arnavud, Müessesetü'rRisale, 1999, hadîs no: 7708, (XIII, 136). 
çıkarmak ister. Ancak Meryem ve oğlu bundan müstesnadır. Allah Teâlâ, o ikisini, âyetteki istiâzenin bereketiyle şeytandan korumuştur. ${ }^{44}$

İmam Mâtürîdî de Hz. Meryem’in korunmuşluğundan “Allah, bir de iffetini sapasağlam koruyan ve bizim de kendisine rubumuzdan üflediğimiz, Rabbinin kelimelerini ve kitaplarm doğrulayan Imran kirs Meryem'i de (inananlara) örnek gösterdi. O itaat edenlerdendi." (Tahrim, 66/12) âyet-i kerimesinin tefsirinde bahseder. Ona göre Hz. Meryem, insanlarla arasına birbirlerini görmelerini engelleyecek bir perde çekmişti. Böylece o, insanları görmediği gibi, insanlar da onu görmüyorlardı. İmam Mâtürîdî̀ye göre bu, "Müminlere söyle, gözlerini sakinsinlar ve iffetlerini korusunlar" (Nur, 24/30) âyetiyle ilişkilidir. Ayrıca o, Âl-i İmran, 3/42 âyetinde geçen $\mathrm{Hz}$. Meryem'in seçilmişliğini ve temizlenmişliğini burayla irtibatlandırarak onun fuhuş ve zinadan korunmuşluğu olarak izah eder. ${ }^{45}$

Kur'an-1 Kerîm, Hz. Meryem'i seçilmiş, temizlenmiş ve dünya kadınlarının en üstünü kılınmış olarak anlatır: "Hani melekler, "Ey Meryem! Allah, seni secti. Seni tertemiz yapt ve seni dünya kadınlarna üstün kıldr." (Âl-i İmran, 3/42). İmam Mâtürîdî, bu âyetin tefsiri bağlamında $\mathrm{Hz}$. Meryem'le konuşan meleğin Cebrail (as) olduğuna dair bir rivayet bulunduğunu, zaten bunun haber dişında herhangi bir yolla bilinemeyeceğini söyler. Şayet bu haber doğru değilse, bu konuşmay1 yapan melek(ler) hakkında bir şey denmemelidir. ${ }^{46}$ Ona göre $\mathrm{Hz}$. Meryem'in seçilmişliği, ibadetinin Allah'a has kılınması veya insanların yaratılışına aykırı bir tarzda Hz. İsa'yı doğurması olarak anlaşılabilir. Temizlenmesi ise, günahlardan ve aşırılıklardan korunması ile hiçbir erkeğin ona temas etmemesi şeklinde yorumlanabilir. Nitekim bu özellikler onu âlemlerin en hayırlı kadını yapmaktadır. İmam Mâtürîdî bu konuda İbn-i Abbas'tan rivayet edilen şu hadîs-i şerifi de aktarır ${ }^{47}$ : Rasulullah (sas) yere dört tane çizgi çizdi ve ardından sordu: Bunların ne olduğunu biliyor musunuz? Oradakiler "Allah ve Rasûlü daha iyi bilir" dediler. Bunun üzerine şöyle buyurdu: Cennet kadınlarının en faziletlileri,

$44 \dot{I}$ şâd $_{3} 3 / 36$ (I, 471).

45 Te'vîlât, 66/12 (XV, 279-281).

46 Bununla birlikte İmam Mâtürîdî, âyette melek ifadesinin çoğul olarak zikredilmesinden bahsetmemekte, dolayisıyla söz konusu rivayet ile çoğul ifade arasındaki farklilığa da temas etmemektedir.

47 Te'vîlât, $3 / 42$ (II, 300-301). 
Hatice, Fâtıma, Meryem ve Firavun'un karısı Âsiye'dir."48 Enes'ten rivayet edilen benzer bir hadîs de şöyledir: "Âlemlerin en hayırlı kadınları dört tanedir: İmran'ın kızı Meryem, Mezâhim'in kızı Âsiye, Hüveylid'in k1z1 Hatice ve Muhammed (sas)'in kız1 Fâtıma."49

Yukarıda aktardığımız Âl-i İmrân,3/42 âyetinde geçen meleklerle ilgili olarak Ebussuûd Efendi bazı görüşler aktarır. Ona göre, buradaki meleklerden maksad Cebrail'dir. Meleklerin onunla konuşması ya $\mathrm{Hz}$. Meryem'in bir kerameti olarak ya da Hz. İsa'nın peygamberliği öncesi mucizelerinden olmak üzere gerçekleşmiştir. Bu ikinci yorum, Allah Teâlâ'nın bir kadını peygamber olarak göndermemesi hakkındaki icmâ sebebiyledir. Âyette yer alan şeçilmişlik, en başından itibaren $\mathrm{Hz}$. Meryem'in, annesinin bir adağ1 olarak kabul edilmesi, ki bir başka kız çocuk daha önce kabul edilmemişti, Hz. Zekeriyya gözetiminde yetiştirilmesi, cennet nimetleriyle rızıklandırılması ve birtakım yüce kerametlerin ona verilmesi bakımındandır. Temizlenmişliği ile kastedilen ise, hem pis kabul edilen durumlardan ve fillerden, hem de baz1 Yahudiler tarafindan kendisine atılan iftiradan, çocuğunun konuşturulması ile arındırılması kastedilmektedir. Âyetin sonunda yer alan âlemdeki diğer kadınlara tercih edilmişlik ile de, babasız olarak $\mathrm{Hz}$. İsa'nın ona verilmesi kastedilmiştir. Zira bu, başka hiçbir kadın için söz konusu değildir. Bundan dolay1 Allah Teâlâ hem Hz. Meryem hem de Hz. İsa'y1 bütün âlemler için âyet k1lmıştır. Meleklerle olan bu konuşmanın, Hz. İsa'nın ona müjdelenmesinden önce olmas1, Hz. Meryem'in bu durumdan önce itaat ve ibadete son derece uygun olduğunu bildirmek içindir. Nitekim o aynı zamanda, emredildiği şeye gayretli, Allah'a yönelen, O'nun yolunda dünyadan vazgeçip iffetli bir hayat süren, diğer insanların şartlarından sıyrılmış, Ruhu'l-Kuds'ün kendisine ulaşmasına hazır bir kimse idi. ${ }^{50}$

Ayrıca Ebussuûd'a göre söz konusu âyette Hz. Meryem'in isminin tekrar ikinci kere zikredilmesi, onun seçimi ve diğer insanlardan ayrılması ile ilgili hususlara gösterilen özenin fazlalı̆̆ını hissettirmek

48 Hâkim en-Nîsâbûrî, el-Müstedrek ale's-Sahihayn, Dâru'l-Kutubi'l-İlmiyye, Beyrut 1990, hadis no: 3836, (II, 539).

49 Tirmizî, Sünen, Dâru’l-Cîl, Beyrut 1998, hadîs no: 3878, (VI, 179).

50 Irşâd, 3/42 (I, 479-480). 
içindir. Nitekim Hz. Meryem, gerek küçüklüğündeki bedensel anlamdaki yetiştirilmesi, gerekse büyüdügünde dinî sorumluluklarla birlikte ruhanî terbiyesi bakımından farklilık arz etmektedir.

İmam Mâtürîdî, yukarıda söz konusu ettiğimiz Tahrim, 66/12 âyetinde Hz. Meryem hakkında geçen "Rabbinin kelimelerini tasdik etti" ibaresindeki kelimeleri ise, "Hani melekler şöyle demişti: "Ey Meryem! Allah, seni kendi tarafindan bir kelime ile müjdeliyor ki, adn Meryem oğlu Isa Mesib'tir. Dünyada da, abirette de itibarl ve Allah'a çok yakm olanlardandir."'" (Âl-i İmran, 3/45) âyetinde geçen Hz. Meryem'in müjdelendiği kelimeler ve "Hani melekler, "Ey Meryem! Allah, seni secti. Seni tertemiz yapt ve seni dünya kadinlarna üstün kaldr. Ey Meryem! Rabbine divan dur. Secde et ve (O'nun bu₹urunda) rükề edenlerle beraber rükûu et" demişlerdi" (Âl-i İmran, 3/42-43) âyetlerindeki ifadeler olarak anlaşılmasinın mümkün olduğu görüşündedir. Dolayısıyla Hz. Meryem bunların tamamını ve Allah katından olduğunu, şeytanın bunlara hiçbir şekilde müdahalede bulunmadığını tasdik etmektedir. Ya da kelimeler ile kastedilen Rabbin hüccetleri, burhanlar1 ve delilleridir. Bunlar da yeniden dirilme, peygamberlik veya tevhide dair hüccetler olabilir. Kelimeler ile kastedilen muhtemel anlamlardan bir diğeri de, Hz. Meryem'in kendileriyle kötülüklerden Allah'a sığındığ1, istiâze ettiği kelimelerdir. ${ }^{51}$

Tahrim sûresinin mezkur âyetinde tasdik edilen diğer bir husus ise "kitaplar" tabiridir. İmam Mâtürîdî̀ye göre bu kelime "kitab" ve "kütüb" şeklinde de okunmuştur. Her iki okuyuş da benzer bir içeriğe sahiptir. Çünkü kitaplardan birini tasdik eden diğerlerini de tasdik etmiş olur. Zira kitaplar birbirine muvafiktır. Dolayısıyla her iki okuyuş tarzı da birbirini gerektirmektedir. "kitap" tabiri esas alınırsa kastedilen İncil olmaktadır. "kütüb" tabirinde ise kastedilen İncil ve Allah tarafindan gönderilen önceki diğer kitaplar olmaktadır. ${ }^{52}$

Âyetin son kısminda yer alan "kânitîn" ifadesi ise İmam Mâtürîlî̀ye göre namaz kilanlar (musallîn) anlamına gelmektedir. Zira Hz. Meryem ile ilgili "Ey Meryem! Rabbine divan dur. Secde et ve (O'nun buzurunda) rükû edenlerle beraber rükêu et" demislerdi." (Âl-i İmran, 3/43) âyetinde buna işâret vardır. Bu âyetteki emre itaat ettiğinde "kânitîn"den

51 Te'vîlât, 66/12 (XV, 279-281).

52 Te'vîlât, 66/12 (XV, 279-281). 
olmuş olur. Diğer bir anlam ise, Hz. Meryem'in Allah'a itaat edenlerden (mutîîn) olmasıdır. ${ }^{53}$

\section{d. Hz. Meryem ve Hz. İsa}

Buraya kadar söz konusu tefsirlerden aktardığımız Hz. Meryem'in diğer insanlardan ahlakî bakımdan daha üstün bir konumda olmasıyla ilgili görüşler, onun henüz $\mathrm{Hz}$. İsa'nın annesi olmasından önceki dönemine aittir. Bununla birlikte Kur'an-1 Kerîm onun sahip olduğu üstün ahlakî niteliklerini Hz. İsa'ya hamile kaldığ1 ve doğurduğu dönem açısından da zikretmeye devam eder. Zira bu hâdise, kişiye yüklemiş olduğu ağırlık bakımından herkesin kaldırabileceği bir durum değildir.

Kur'an-1 Kerîm, Hz. Meryem'in henüz melek ile görüşmesinden önce uzlete çekildiğinden, diğer peygamberlerin anıldığ1 bir üslupla, şu şekilde bahseder: "(Ey Muhammed!) Kitap'ta Meryem'i de an. Hani ailesinden ayrlarak doğu tarafinda bir yere çekilmisti." (Meryem, 19/16). Bu, onun ne kadar ağır bir görevin altında bulunduğunun ilahî bir takdirle ifadesi olsa gerektir. İmam Mâtürîdî, onun âilesinden ayrılması hadisesini, kadınlık yaşına geldiğinde kendisini yabancıların bakışlarından koruma maksadına yönelik olduğunu kaydeder. Dolayısıyla Hz. Meryem'in iffetinin ve temizliğinin korunması onun bütün hayat safahatını ihtiva eder. Hz. Meryem'in ailesinden ayrılarak çekildiği “doğu tarafi” hakkında verdiği "çünkü o zaman kış idi” yorumu, güneş gören ve dolayısıyla sıcak olan bir yer imasından öteye gitmez. Bu yer hakkında tefsirde ayrıntılı bir bilgi yoktur. ${ }^{54}$ Ebussuûd Efendi ise, onun insanlardan uzak bir yere, kendi başına çekilmesinin, yalnız kalarak Allah'a ibadet kasdını taşıdığını belirtir. Bu olayla ilgili olarak ayrıca, Hz. Meryem'in duvar gibi bir şeyin arkasına gizlenerek yıkanmak maksadıyla siperlikli bir yere oturduğu söylenmektedir. Nitekim bir sonraki âyette geçen "onlarla arasına bir perde çekmişti” (Meryem, 19/17) ifadesi bunu anlatmaktadır. Ona göre Hz. Meryem'in bulunduğu yer mâbed idi. Hayız gördüğünde teyzesinin evine gidiyor, temizlendikten sonra da mâbede geri dönüyordu. ${ }^{55} \mathrm{Bu}$ bilgiye

\footnotetext{
Te'vîlât, 66/12 (XV, 279-281).

Te'vîlât, 19/16 (IX, 125-126).

İrsâd, 19/16 (III, 574).
} 
göre, Hz. Meryem'in bulunduğu yer, mâbed içinde kendisine tahsis edilen yerdi.

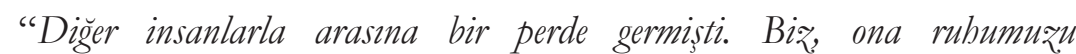
göndermisstik de ona tam bir insan şeklinde görünmüstü" (Meryem, 19/17) âyet-i kerîmesi, Allah Teâlâ'nın Hz. Meryem'e "ruh" gönderdiğinden bahseder. İmam Mâtürîdî, Übey İbn Ka'b’ın bu konudaki farklı görüşünü (ruh kelimesine, Hz. İsa'nın ruhu anlamını verir) zikrettikten sonra tefsir ehlinin ortak görüşü olarak âyette geçen "ruh"un Cebraîl (as) olduğunu belirtir. Nitekim "Ey Muhammed! De ki: Rubu'l-Kuds, inananlarm inançlarm sağlamlastrmak, müslümanlara doğru yolu göstermek ve onlara bir müjde olmak. üzere Kur'an'ı Rabbinden hak olarak indirdi” (Nahl, 16/102) âyetinde geçen ruh kelimesi de bu anlama gelmektedir. Ruhun niteliği olarak zikredilen "beşeran seviyyâ" ifadesi ise onun kusursuz, noksansiz ve tam bir insan olarak göründüğünü ifade etmektedir. ${ }^{56}$

Ebussuûd Efendi’nin aktardığına göre, yukarıda geçtiği üzere $\mathrm{Hz}$. Meryem, yıkandığ1 yerde bulunurken, yanına bir melek geldi. Bu melek, henüz bıyığ1 çıkmamış, parlak yüzlü, kıvırcık saçlı, genç bir insan görünümünde idi. Nitekim âyette yer alan "Biæ, ona rubumuzu gönderdik" ifadesi bu olay hakkındadır. Ona göre Hz. Meryem'e gönderilen melek Cebrail (as)'dir. Onun bu âyette "ruh" olarak anılması, sahip olduğu konumun sorumluluğunu yerine getirmesi sebebiyledir. Bununla birlikle "ruh" kelimesi, serinlik veren esinti ya da rahatlik anlaminda "revh" şeklinde de okunmuştur. Bu ise, onun, "eğer ölen kimse Allah'a yakın olanlardan ise, onun için rahatllk, güzel nasip ve naîm cenneti varder" (Vâkia, 56/88-89) âyetinde geçtiği gibi, Allah'a yakınlaşmış kulların bir özelliği olan rahatlığın sebebi olması dolayısıyladır. Ebussuûd âyette yer alan "beşeran seviyya" ifadesiyle ilgili olarak, düzgün bir yaratılış, ve insanlara ait güzellikten hiçbir şeyin eksik olmadiğ1 mükemmel bir bünye açıklamasını getirir. Ayrıca şöyle bir alıntıdan bahseder: Cebrail (as), Hz. Meryem'e kendisinin yaşıtı olan Beytü'l-Makdis'te hizmet eden Yusuf isminde birisi suretinde göründüğü söylenmektedir. $\mathrm{Bu}$ ise, $\mathrm{Hz}$. Meryem'in onun sözlerine yabancillk çekmemesi, Rabbinden getirdiği kelimeleri kabul etmesi içindir. Zira eğer ona melek suretinde görünmüş olsayd1, ondan çekinir ve onunla görüşmeyi gerçekleştiremezdi. Diğer bir

56 Te’vîlât, 19/17 (IX, 126). Cebrail (as)'in Hz. Meryem'e insan suretinde görünüp ona bir çocuk müjdelemesine dair bilgi Luka, 1: 26-38'de geçmektedir. 
görüşe göre ise, Cebrail (as)'in Hz. Meryem'e kusursuz bir insan suretinde görünmesi, onun arzularını heyecana getirip yumurtasının rahmine inmesini sağlamak içindir. Ona göre bu görüş, ilahî kudretin bir mucizesinden bahsedildiği böyle bir yere aykırı olmasının yanı sıra, hemen arkasindan gelen "Meryem, "Senden, Rahmân'a siğgnım. Ĕger muttakî biri isen (bana kötuilïk etme)" dedi" (Meryem, 19/18) âyeti tarafindan da yalanlanmaktadır. Bu âyet, Hz. Meryem'in ona meylettiğine dair herhangi bir şâibenin hatıra gelmemesi için âdil bir şâhid konumundadır. Cebrail (as)'in fevkalade güzel bir görünümde olmas1, Hz. Meryem'i imtihan etmek, onun iffetini sınamak içindir. Nitekim Hz. Meryem, daha ötesi olmayan bir takva ve iffet durumu sergilemiştir. Âyette Hz. Meryem'in Allah'1 "Rahman" olarak anması ise, başına gelen şeylerden masumiyetini koruyarak çıkmasına yönelik Allah'ın hususi rahmetini talep etmek içindir. ${ }^{57}$

"Meryem, "Senden, Rahmân'a siğgnmm. Ĕger Allab'tan çekinen biri isen (bana kötülïk etme)" dedi." âyet-i kerîmesi, Hz. Meryem'in, Cebrail ile olan bu ilk karşılaşmasında, bu tanımadığı insandan gelebilecek herhangi bir kötülüğe karşı Allah’a sı̆̆ındığını dile getirir.

Bu karşılaşmada Cebraîl (as), Hz. Meryem'e, "Ben ancak Rabbinin elçisiyim. Sana tertemiz, bir çocuk bağģ̧lamak için gönderildim” (Meryem, 19/19) der. İmam Mâtürîdî, bu ifadelerde bir kapalılık olduğunu, hediyenin Cebraîl'e değil Allah'a aidiyeti anlaşılacak şekilde izah eder. Nitekim âyetteki "liehebe" (vermem için) ifadesi hakkında İbn Mesud'dan farklı bir şekilde gelen "liyehebe" (vermesi için) kıraatini de buna delil olarak gösterir. Âyette Hz. İsa'nın sıfatı olarak zikredilen "zekî" tabiri ise, sâlih ve her türlü kötülüklerden arınmış anlamında yorumlanır. ${ }^{58}$ Ebussuûd Efendi de, âyette yer alan "liehebe" ifadesinin "liyehebe" şeklindeki kıraatinin, buradaki sözün Allah'a ait olduğunu desteklediğini ifade eder. Âyette yer alan “zek̂̂” ifadesini de, günahlardan arındırılmış, iyilik üzere büyüyen, yani yaşı ilerledikçe hayır ve iyilik üzere gelişen şeklinde yorumlar. ${ }^{59}$

\footnotetext{
57 İrsâd, 19/16-18 (III, 574-576).

58 Te'vilât, 19/19 (IX, 127).

59 İrşâd, 19/19, (III, 576).
} 
Hz. Meryem, bu sözler karșısındaki șașkınlığını, "Bana biç̧ir insan dokunmadı̆̆ ve iffetsiz, bir kadin olmadiğrm hâlde, benim nasıl çocuğum olabilir?" (Meryem, 19/20) şeklinde ifade eder. İmam Mâtürîdî, "dokunmama" ve "iffetsiz olmama" sözlerini, evlilik içi ve evlilik dışı herhangi bir şekilde cinsel ilişkiye girmemiş olma şeklinde değerlendirir. Çünkü ona göre Hz. Meryem, bir çocuk sahibi olmanın ancak bu şekilde bir sebebe bağlı olarak meydana gelebileceğini düşünmektedir. ${ }^{60}$ Ebussuûd Efendi de bu âyeti tefsir ederken, Hz. Meryem'e hiçbir insan dokunmamasını, onun hiçbir erkekle evlenerek birlikte olmadığı, iffetsiz bir kadın olmamasını da, erkekleri arzu eden bir günahkâr olmadığı şeklinde açıklar. ${ }^{61}$

Cebraîl (as), Hz. Meryem'e “Evet, öyle. Rabbin diyor ki: O benim için çok kolaydır. Onu insanlara bir muciz̨e, katımızdan bir rabmet kılmak için böyle takdir ettik. Bu, zaten bükeme bağlanmıs bir iştir" (Meryem, 19/21) şeklinde cevap verir: İmam Mâtürîdî, Allah Teâlâ'ya kolay gelen şeyin, bir sebebe bağlı veya sebepsiz yaratmanın O'nun için zor olmaması anlamına geldiğini belirtir. Onun aktardığına göre âyette geçen "kezalik" (öyle) ifadesini baz1 müfessirler, bu olayın daha önceki peygamberlere bildirildiği ve onların da kendi halklarına böyle bir şeyin gerçekleşeceğine dair haber verdiklerini ileri sürerler. Dolayısıyla Hz. İsa'nın mucize oluşu iki açıdan gerçekleşmektedir. Birincisi, önceki peygamberlerin verdikleri haberin doğru çıkması şeklindedir ki, böylece Hz. İsa onların verdikleri haberin doğruluğuna delil teşkil etmektedir. İkincisi ise onun babasız bir şekilde dünyaya gelmesidir. ${ }^{62}$

Hiristiyanlara göre, Hz. İsa (as)'nın müjdesi Eski Ahit'te yer almaktadır. Esk-i Ahit'in "Bunun için Rab kendisi size bir alamet verecek; işte, kız gebe kalacak, ve bir oğul doğuracak, ve onun adını İmmanuel (Allah bizimle) koyacak." (İşaya, 7:14) örneğinde olduğu gibi farklı pasajlarında Hz. İsa'nın geleceğini müjdeleyen ifadeler bulunmaktadır. Ayrıca Hiristiyanlara göre Yahudiler arasinda beklenen Mesih, Hz. İsa'dır. Yeni Ahit’te yer alan "Kitapları araştırıyorsunuz, siz

\footnotetext{
60 Te'vîlât, 19/20 (IX, 127).

61 İşâd, 19/20 (III, 576).

62 Te'vîlât, 19/20 (IX, 127).
} 
ebedî hayatın onlarda olduğunu sanıyorsunuz; benim hakkımda șehadet edenler de onlardır." (Yuhanna, 5:39) gibi ifadeler bunu göstermektedir. ${ }^{63}$

Diğer taraftan Kur'an-1 Kerîm de, Hz. İsa'nin önceden haber verildiğini bildirmektedir: "Zekeriyya mâbedde durmus namaz kilarlarken melekler ona sö̈le seslendiler: Allah sana kendisi tarafindan gelen bir kelimeyi tasdike edici, efendi, iffetli ve Saliblerden bir peygamber olarak Yabya'y müjdeler." (Âl-i İmran, 3/39). Bu âyette yer alan kelime tabirinin, aynı sûrenin 45. âyetinde Hz. İsa olduğu açıkça ifade edilmektedir. Aynı zamanda Kur'an1 Kerîm Hz. İsa'yı Mesih olarak isimlendirmekle, Yahudilerin bekledikleri kurtarıcıyı da onaylamış olmaktadır. Dolayısıyla İmam Mâtürîdînnin aktardığı bu görüş, Hıristiyan kaynaklarına atıfta bulunmadan da ileri sürülebilir görülmektedir.

Ayrıca Mâtürîdîye göre Hz. İsa'nın babasız doğmasının, insanlar için yeniden dirilmeye dair bir delil olarak görülmesi de mümkündür. Çünkü Allah Teâlâ onu babasız ve sebepsiz yaratmıştır. Zira insanlar yeniden dirilmeyi ve bir şeyin sebepsiz olması fikrini inkâr ediyorlardı. İmam Mâtürîdî, âyette geçen "katımızdan bir rahmet" ibaresini, insanlar için bir kurtuluş olarak yorumlar. Çünkü kim onun rehberliğini kabul eder ve ittiba ederse kurtuluşa erer*. $\mathrm{Bu}$ bağlamda o bütün peygamberlerin Allah katından bir rahmet olduğunu söyler ve $\mathrm{Hz}$. Peygamber hakkindaki "Bį, seni ancak âlemlere rahmet olarak gönderdik" (Enbiyâ, 21/107) âyetiyle ilişkilendirir. ${ }^{64}$ Ayrıca İmam Mâtürîdî, Âl-i İmrân, 3/47 âyetini yorumlarken, Cebrail (as)'1n verdiği cevaba dayanarak, Hz. Meryem'in hiç evlenmeyeceğini anladığını söyler. Çünkü o, Allah'a adanmış ve O'na ibadete halis kılınmıştır. ${ }^{65}$ İmam Mâtürîdînnin belirttiği şekliyle Hz. Meryem’in ömrü boyunca hiç evlenmediği fikri

63 Hz. İsa'nın Eski Ahit'te müjdelendiğine dair daha geniş bilgi için bkz. W.C. Placher, A History of Christian Theology, Philadelphia 1983, ss. 28-30; Adrian Rogers, "A Portrait of Christ", http://www.oneplace.com/ministries/love-worthfinding/read/articles/a-portrait-of-christ-10200.html (20.10.2015).

* "Kurtarıc1" vasfi Hiristiyanlar tarafindan Hz. İsa hakkında en yaygin olarak kullanılan niteliklerdendir. Özellikle Yeni Ahit Hz. İsa'dan sıklıkla kurtarıc1 olarak söz eder; örneğin bkz. Luka, 1:19, 2:10; Yuhanna, 4:42, Rasullerin İşleri, 5:31, 7:35, 13:23.

64 Te'vîlât, 19/20 (IX, 127).

65 Te'vîlât, 3/47 (II, 305-307). 
Hıristiyan kaynaklarında tartışmalı bir husustur. İncil'de Hz. İsa'nın dört erkek kardeşinin ad1 sayılır (bkz. Markos, 6:3, Matta, 13:55); Hz. Meryem'in Yusufla evlendiği belirtilir (Matta, 1:16, 1:20; Luka, 1:26; Yuhanna 1:45 vd.). Bununla birlikte baz1 Hiristiyanlar Hz. Meryem'in ömrü boyunca bakire kaldığı ve hiç evlenmediği görüşünü benimserler. ${ }^{66}$ Onlara göre söz konusu İncillerde kullanılan kardeş tabiri, nesebi bir bağ1 ifade etmemektedir; Matta ve Markos'ta isimleri zikredilen kardeşler ise, Hz. Meryem'in değil, ya nişanlısı Yusuf'un çocuklarıdır ya da Hz. İsa'nın kuzenleridir. ${ }^{67}$ Bazı müslüman kaynaklarında Hz. Meryem ile Yusuf arasındaki ilişkiden bahsedilmesine rağmen ${ }^{68}$ İmam Mâtürîdî bu konuya hiç temas etmez. Dolayısıyla o, Kur'an-1 Kerîm'in ilgili âyetlerinden Hz. Meryem'in hiç evlenmediği ve Hz. İsa'dan başka çocuğu olmadığ sonucuna ulaşmaktadır. Muhtemelen o, Kur'an'ın Hz. Meryem hakkında kullandığı “iffet" vasfi açısından bunun daha doğru olduğunu düşünmektedir.

İmam Mâtürîdî, Hz. İsa'nın babasız yaratılmasını, babasız ve annesiz yaratılan Hz. Âdem ile, birbirlerinden doğmayan gece ve gündüzün yaratılmasına benzetir. Dolayısıyla, âyette geçen "kezâlike" ifadesi, Hz. Meryem'e, hiç kimse sana dokunmadan ve babası olmadan Allah sana bir çocuk yaratacaktır, anlamına gelir. ${ }^{69}$ Ebussuûd Efendi de, "kezâlik" tabiriyle ilgili olarak, Allah katından gelen emrin böyle olduğunu söyler.

Ebussuûd Efendi, konuyla ilgili olarak "Hani melekler sö̈le demisti:"Ey Meryem! Allah, seni kendi tarafindan bir kelime ile müjdeliyor ki, adn Meryem oğlu İsa Mesib'tir. Dünyada da, abirette de itibarl ve Allab'a çok yakem olanlardandı" (Âl-i İmrân, 3/45) âyetini tefsir ederken, Hz. İsa'nun bu âyette üç isimle birden zikredildiğine temas etmektedir ki, bu durum onu kendisinin dışındaki herkesten ayırmaktadır. Ona göre, âyette ondan İbnu Meryem olarak bahsedilmesi de, onun babasız olarak doğmasina ve dolayısıyla annesinden başkasına nispet edilememesine tenbihtir. Nitekim

\footnotetext{
66 Bkz. Tümer, age, ss. 108-109.

67 Daha geniş bilgi için bkz. Ahmed Bedir, "Kur'an ve İncillere Göre Hz. İsa'nın Var Olduğu İleri Sürülen Kardeşleri Meselesi”, Harran Üniversitesi Ilabiyat Fakültesi Dergisi, IV (1998), ss. 124-129.

68 Bkz. Tümer, age, ss. 161-163.

69 Te'vîlât, 3/47 (II, 305-307).
} 
Hz. Meryem de, bununla bütün kadınların üzerinde bir fazilet kazanmıștır. ${ }^{70}$

Ebussuûd, "(Meryem), "Ey Rabbim! Bana bir beșer dokunmamıskeen benim nasıl çocuğum olur?" dedi. Allah, "Öyle, Allah dilediğini yaratır. O, bir seyin olmasin dilediğinde ona sadece "ol" der, o da hemen oluverir" dedi" (Âl-i İmrân, 3/47) âyetini tefsir ederken, Hz. Meryem'in sorusunu, insanların normal durumlarını göz önünde bulundurmasından dolayı, merak saikiyle sorulmuş bir soru olarak değerlendirir. Çünkü Hz. Meryem, kendi durumunu çocuk sahibi olmaya elverişsiz görmektedir. Ayrıca burada Ebussuûd'a göre $\mathrm{Hz}$. Zekeriyya'nın hanımı ile karşılaştırma söz konusudur. Zira bakire bir bayanın, bir erkek ile ilişkisi olmaksızın çocuk sahibi olması, yaşlı ve kısır bir kadınınkinden çok daha fazla garip ve şaşırtıcıdır. ${ }^{71}$

\section{Hz. Meryem'in Hamileliği}

Kur'an-1 Kerîm Hz. Meryem'in Cebrail (as) ile görüşmesinden sonra hamile kalmasından birkaç yerde bahseder. Örneğin Enbiyâ sûresinde bu olayla ilgili olarak şöyle bahsedilir: "Iræum korumus olan kadm da (Meryem'i de) hatrrla. Ona rubumuzdan üflemistik. Kendisini de, oğlunu da âlemlere (kudretimiz̨i gösteren) bir âyet yapmıștı.." (Enbiyâ, 21/91). İmam Mâtürîdî, âyette geçen "ruh üfleme" hadisesi hakkinda, bunun Cebraîl (as) tarafindan gerçekleştirildiği şeklindeki yorumları doğru bulmaz. Zira âyette böyle bir kayıt yoktur. Ayrıca benzer bir âyet Hz. Âdem hakkında da mevcuttur: "Ona rubumdan üfledim" (Hicr,15/29; Sâd,38/72). Ona göre burada geçen "üfleme" fiili, inşâ etmek, yaratmak anlamına gelmektedir. Ayrica âyette Hz. Meryem ve Hz. İsa'ya tek bir âyet/mucize isnad edilmesini de, Hz. Meryem'in kocasız doğum yapması, Hz. İsa'nın da

$70 \dot{I}$ rşâd, $3 / 45$ (I, 482). Âyette bahsedilen diğer isimleri ise şöyle açıklar: Mesîh, Hz. İsa'nın lakabıdır. İbranice aslı Meşiha olup mübarek anlamına gelmektedir. İsa kelimesi ise, Îșû́ kelimesinin Arapçalașmıș halidir. Hz. İsa’ya Mesih denmesi, onun bereketle meshedilmesi (dokunulmasi), ya da günahlardan temizlenmesi, ya da Cebrail'in onu meshetmesi, ya da yeryüzünde dolaşması ve hiçbir yerde ikamet etmemesi, hastaları, onlara dokunarak tedavi etmesi sebebiyledir.

71 İşâd, 3/47 (I, 483). 
babasız dünyaya gelmesi olduğunu söyler. Bunu iki kişinin söz konusu olduğu tek bir mucize olarak değerlendirir. ${ }^{72}$

İmam Mâtürîdî, Tahrim, 66/12 âyetinde geçen "ruh üfleme" tabirini tefsir ederken de benzer bir şekilde bunun yaratma olduğunu kabul eder. Ona göre buradaki ibare "onda (fihi), kendisiyle bedenlerin ve suretlerin hayat bulduğu şeyi yarattık" anlamina gelmektedir. Âyette geçen "hu" zamiri ona göre Hz. Meryem'in fercine, yani kadınlık organına dönmektedir. Nitekim başka bir âyette "fihi" yerine "fihâ" demektedir ki (Enbiyâ, 21/91) burada da "ha" zamiri bizzat Hz. Meryem'e dönmektedir. Tefsirde değinilen diğer bir husus ise yaratma ile üfleme arasındaki benzerliğin izahıdır. Buna göre söz konusu iki olgu arasındaki benzerlik, ya ruhun bedende yaratıldığ zaman aynen rüzgar (rîh) gibi yayılması sebebiyle ya da aynen rüzgarda olduğu gibi, ruhun üflendiği şeye süratli bir şekilde girmesi münasebetiyle kurulmuştur. ${ }^{73}$ Görüldüğü gibi Mâtürîdî̀ye göre ruh kelimesinin etimolojik olarak rüzgar (rîh) ile olan bağlantısı, ruhun üflenmek suretiyle bedene girip onu canlı kılması ve dolayısıyla yaratmayı ifade etmesiyle ilişkilendirilmektedir.

Ebussuûd Efendi "Ey Kitab ebli! Dininizde sinrrlar aşmayn ve Allah bakkinda ancak bakekr söyleyin. Meryem oğlu İsa Mesih, ancake Allab'm peygamberi, Meryem'e ulaştırdı̆̆ kelimesi ve kendisinden bir rubtur..." (Nisâ, 4/171) âyetinin tefsirinde ruh üflenmesi hâdisesini şöyle açıklar: Cebrail aleyhisselam Hz. Meryem'in göğsüne (veya elbisesine) üflemiş, o da Allah'in izniyle hamile kalmıştır. Üfleme âyette ruh olarak isimlendirilmiştir, zira o ruhtan çıkan bir rüzgârdır. Bu ifade başlangıçta tamamen mecâzî bir anlam taşıyordu; Hıristiyanların zannettiği gibi "ondan bir parça olmak" anlamı yoktu. Ebussuûd Efendi bu konuyla ilgili Harun er-Reşî̀ zamanında Hıristiyan bir hekim ile el-Vâkıdî elMervezî arasında geçen bir tartışmaya da yer verir. Ayrıca o, âyette yer alan ruh kelimesiyle ilgili farklı yorumlardan da bahseder. Örneğin, Hz. İsa'nın ruh olarak isimlendirilmesi, ölüleri diriltmesi sebebiyledir. Nitekim, kalpleri diriltiyor olması sebebiyle Şûrâ,42/52. âyetinde Kur'an-1 Kerîm'e de ruh ismi verilmiştir. ${ }^{74}$

\footnotetext{
72 Te'vilât, 21/91 (IX, 319-320).

73 Te'vîlât, 66/12 (XV, 279-281).

74 İş̧âd, 4/171 (I, 821).
} 
Hz. Meryem'in hamilelik dönemiyle ilgili olarak Ebussuûd Efendi, Süddî'den şöyle bir rivayette bulunur: Bir gün Hz. Yahya'nın annesi Hz. Meryem'e uğrar. "Ey Meryem! Hamile olduğumu işittin mi?" diye sorar. Hz. Meryem de "ben de hamileyim" diye cevap verir. Bunun üzerine Hz. Yahya'nın annesi "ben senin karnındakini buldum (bildim)" der. İşte Allah Teâlâ’nın Hz. Yahya hakkında kullandığı “...kelimeyi tasdike eden..." sözü budur. Hz. Meryem doğum yaptığında 13 veya 10 yaşındadır. ${ }^{75}$

\section{Hz. İsa'nun Doğumu}

Cebraîl (as) ile bu karşılaşma sonrasını Kur'an-1 Kerîm şu ifadelerle aç1klar: "Sonra çocuğuna hamile kaldr ve bu baliyle u₹̧akça bir yere çekildi. Doğum sancısı onu bir hurma ăgacma yöneltti. "Keşke bundan önce ölseydim de unutulup gitmiş olsaydım!" dedi" (Meryem, 19/22-23). İmam Mâtürîdî, bu âyetle ilgili olarak bazı müfessirlerden alıntı yaparak, doğum anının yaklaşmasından kaynaklanan ihtiyacın onu kuru bir hurma ağacinın yanına getirdiğini, arkasından söylediği sözlerin ise, ya doğum sancısının verdiği 1zdıraptan ya da kendisine atılan iftiranın verdiği acıdan kaynaklandığını hatırlatır. ${ }^{76}$ Ebussuûd Efendi ise bu âyetlerle ilgili olarak şunlar1 kaydeder: Hz. Meryem'in hamileliğinin ne kadar sürdüğü konusunda farklı görüşler mevcuttur: Hamileliğinin yedi ay, sekiz ay, dokuz ay sürdüğunnü söyleyenler olduğu gibi, üç saat ve bir saat olduğunu söyleyenler de vardır. Hamile kaldığında Hz. Meryem'in kaç yaşında olduğu hususunda da ihtilaflar vardır: bazıları o sırada on üç yaşında olduğunu söylerken bazıları, iki defa âdet görmüş olup on yaşında olduğunu söylerler. Aynı âyette geçen Hz. Meryem'in uzak bir yere çekilmesini ise şöyle açıklar: Çekildiği yer, âilesinden uzak, dağın ötesinde bir yerdir. Diğer bir görüşe göre de evin uzak bir köşesi kastedilmiştir ki, hamileliğinin kısalı̆ 1 sebebiyle bu daha uygundur. ${ }^{77}$ Ebussuûd'un

75 İşâd, 3/39 (I, 475-476). Hz. Meryem ile Hz. Yahya’nın annesinin karşılaşmasına, onun müjdesine Luka İncili'nde de temas edilmektedir. Buraya göre, Ruhu'l-Kuds ile karşılaşmasından sonra Hz. Meryem teyzesi Elisabet'in yanına gider. Onu göre Elisabet şöyle der: “...Çünkü işte senin selamın sesi kulağıma erdiği anda, çocuk karnımda sevinçten sıçradı. İman eden kadına ne mutlu! Çünkü Rab tarafindan kendisine söylenen şeyler tamam olacaktır.” (Luka, 1:44-45).

76 Te'vîlât, 19/23 (IX, 129-130).

77 İşâd, 19/21(III, 577). 
aktardığ1 doğuma ilişkin bu ayrıntılar, muhtemelen Hıristiyan halk arasında anlatılan söylenceler olmalıdır. Nitekim bu detaylar, olağanüstü doğum olayının mahiyetine uygun bir karaktere sahiptirler. ${ }^{78}$

Ebussuûd Efendi'nin aktardığına göre, Hz. Meryem'in hurma ağacına yönelmesi, hem gizlenmesi hem doğum sirasında ona dayanması içindi. Bu hurma ağac1 kuru idi, üst taraf1 ve yeşilliği yoktu. Mevsim de kıştı. Muhtemelen oraya gitmesini, korkusunu gidermek ve kendisine uygun bir doğum yemeği yedirmek şeklindeki mucizelerini göstermek için Allah Teâlâ ona ilham etmişti. Hz. Meryem'in, Cebrail (as) ile görüşmesine rağmen "Keşke bundan önce ölseydim de unutulup gitmis olsaydım?" demesi ise, insanlardan utanması ve onların kendini kinamasindan korkması, ya da insanların ondan günahkâr olarak bahsetmelerinden endişe etmesi veyahut sâlih kulların işler kötüye gittiğinde yaptıkları gibi yapması sebebiyledir. Nitekim Hz. Ömer'den rivayet edildiğine göre, o yerden bir saman çöpü almış ve "keşke hiçbir şey olmadan, şu çöp gibi olsaydım” demiştir. Hz. Bilal'den de, şöyle rivayet edilmiştir: "Keşke annesi Bilal'i doğurmasaydı". ${ }^{79}$

Bu haldeyken Hz. Meryem, alt tarafindan bir ses duyar: "Üzülme! Rabbin sana altında bir dere yarattl." (Meryem, 19/24). İmam Mâtürîdî, Hz. Meryem'in duyduğu bu sesin kime ait olduğu yolunda ileri sürülen üç görüşe yer verir: Bir melek, Hz. İsa ve Cebraîl (as). Ebu Bekir elEsamm'ın bu sesin melek olamayacağına dair itirazını ise anlamsız görür. Hz. Meryem'in üzülme sebebi olarak ise, ya kendisine atılan iftira ya da bulunduğu yerde su bulunmamasından ötürü kendi ve doğmakta olan çocuğu hakkında duyduğu endişe ihtimallerini zikreder. Âyette yer alan küçük bir su akıntısının yaratılmasını da bu durumla ilişkilendirir. Zira "seriyyâ" tabiri, su arkı ve küçük ırmak anlamlarına gelmektedir. Ayrıca İmam Mâtürîdîye göre $\mathrm{Hz}$. Meryem'in burada ses işitmesi ile $\mathrm{Hz}$. Musa'nın Tuvâ vadisinde işittiğgi ses arasında benzerlik vardır. Çünkü

78 Hz. Meryem'in doğumu nerede gerçekleştirdiği ile ilgili Hıristiyan kaynaklarında farklı bilgiler mevcuttur. Luka İncili'ne göre, Hz. Meryem hamile kaldıktan sonra nişanlısı Yusuf ile birlikte Beytü'l-Lahm'e gittiler ve doğum orada bir koyun ağılında gerçekleşti. Bkz. Luka, 2: 4-7. Yakup İncili’ne göre ise, doğum Beytü’l-Lahm yakınlarında bir mağarada bir ebe tarafindan gerçekleştirilmiştir. Ayrıca doğum sırasında ortaya çıkan bazı olağanüstü durumlardan da bahsedilir. Bkz. Yakup İncili, VIII: 1-2, IX:1-2, (Sarıkç1oğlu, age, s. 58-59).

79 İşâd, 19/23 (III, 577-578). 
Allah Teâlâ dilediği kimseye, dilediği șeyi, dilediği şekilde ișittirir ve bildirir. Dolayısıyla Allah Teâlâ'nın işittirmek istediği şey, Hz. Musa kıssasında olduğu gibi ağaç tarafindan olabileceği gibi, bu kıssada olduğu üzere alt taraftan da olabilir. ${ }^{80}$

Ebussuûd Efendi söz konusu âyetin tefsirinde altından seslenenin kim olduğu konusunda farklı görüşlere yer verir. Bazılarına göre bu $\mathrm{Hz}$. Meryem'in bulunduğu tepenin alt tarafinda duran Cebrail (as), bazılarına göre ise o sırada doğmakta olan Hz. İsa (as)'dır. İbn-i Abbas'tan merfu olarak rivayet edildiğine göre, Cebrail (as) ayağını yere vurmuş, bunun üzerine bir tatlı su pinarı ortaya çıkmış ve akmaya başlamıştır. Bazıları bunu yapanın $\mathrm{Hz}$. İsa olduğunu söylerler. Bazılarına göre de, orada kurumuş bir dere vardı. Allah Teâlâ kurumuş, yapraksız ve meyvesiz hurma ağacını yeşertmesi gibi, o dereyi de akıtmaya başlattı. Bazıları ise orada zaten akan bir dere olduğunu söylerler. Ancak Ebussuûd'a göre, âyetin nazmı ve mucizelerin ifade edildiği bir makam olması hasebiyle dere hakkındaki bu iki görüşten birincisi daha doğrudur. Ayrıca âyette geçen ve küçük dere anlamına gelen "seriyyâ" kelimesi için seyyid/efendi, şânı yüce nebî/peygamber anlamları da verilmiştir ki, bu da Hz. İsa'dır. Âyetteki bu ifadeler Hz. Meryem'in üzüntüsünü izale etmek içindir. ${ }^{81}$

$\mathrm{Bu}$ olay esnasinda ayrıca Hz. Meryem'e yanında durduğu hurma ağacını sallaması ve böylece üstündeki hurmaların dökülmesi söylenir (Meryem, 19/25). İmam Mâtürîdî̀ye göre bu âyet, peygamber olmayanların da, peygamberlere verilen mucizelere benzer şeylere mazhar olabileceklerine işaret etmektedir. Zira Hz. Meryem için kuru hurma ağacı yeşertilmiş ve hurma verir hale getirilmiştir. Ayrıca hemen yanında ihtiyaç duyduğu bir su akıtılmış ve Allah Teâlâ onu kendi katından rızıklandırmıştır. Bütün bunlar Hz. Meryem için bir imtihan olduğu gibi, onun Allah katındaki değerini gösteren delâletlerdir. Nitekim Allah Teâlâ seçmiş, temizlemiş ve bütün kadınlardan üstün tutmuş olmasinın yanında, onu "sıddîka" (Mâide, 5/75) olarak isimlendirmiştir. Bu isim ise

So Te'vîlât, 19/23 (IX, 129-130); 28/30 (XI, 34).

81 İşâad, 19/24 (III, 578-579). 
ancak doğruluk ve sabırda en son mertebeye ulaşanlar için kullanılmaktadır. ${ }^{82}$

İmam Mâtürî̀ı’nin bu görüşü, Ehl-i Sünnet ile Mutezile arasında tartışmalı bir konu olan keramet meselesi ile ilgilidir. Daha önce de temas ettiğimiz gibi Hz. Meryem'e Ruhu'l-Kuds gelmeden önce henüz o mabedeyken Allah katından nimetler verilmesi de bu tür bir olaydır. Hem İmam Mâtürîdî hem de Ebussuûd Efendi, bu olayların olağanüstülügüüü hatırlatarak keramet nev'inden olduklarını ifade etmektedirler. Ehl-i Sünnet'in hemen tamamının yanı sıra Ebû Hanife'den itibaren Mâtürîdîlerin de kerameti hak olarak görmeleri ${ }^{83}$ ve bu konuyu Mu’tezile ile bir ihtilaf meselesi haline getirmelerinde yukarıda görüldüğü üzere Kur'an'a bağlı yorumların etkili olduğunu söyleyebiliriz. Zira Mu'tezile'ye göre, peygamberlerin gösterdiği mucize dışında olağanüstü hallerin varlığını kabul etmek, mucizenin, peygamberliği isbat konusundaki konumunu tehlikeye atmaktadır. Oysa Ehl-i Sünnet'e göre peygamberler dışında, buradaki örnekte olduğu gibi, olağanüstü hallerin varlığı, mucizenin delaletine aykırı olmadığ1 gibi, onu desteklemektedir de. Çünkü bu olayların var olması, Allah Teâlâ'nın yaratmasından başka bir şekilde gerçekleşemez. Söz konusu olağanüstü durumlar peygamberliğin ispatı dışında başka amaçlar ve hikmetler için de yaratılabilir.

Ebussuûd Efendi, Hz. Meryem'in Hz. İsa'yı doğurmasıly ilgili tarihçilere atfettiği bazı görüşler aktarmaktadır. Buna göre, Hz. Meryem hamile kaldığında on üç yaşındaydı. Doğumu Evrâ Şelem bölgesinde Beytü'l-Lahm'de gerçekleştirdi. İskender'in Bâbil'e karș1 gâlip gelmesinden sonra 65 sene geçmişti. Allah Teala Hz. İsa'ya 30 yaşındayken vahyetmeye başladı; ve onu Beytü'l-Makdis'ten kadir gecesinde 33 yaşındayken kendi katına yükseltti. Annesi onun yükseltilmesinden sonra altı yıl daha yaşadı. ${ }^{84}$

82 Te’vîlât, 19/25 (IX, 131).

83 Bkz. Süleyman Uludağ, "Keramet”, Dİ, XXV, 266.

84 İşâd, 3/54 (I, 492). Hiristiyan kaynaklara göre de Hz. Meryem'in hamileliği on üçon dört yaşlarında olmalıdır. Bkz. Tümer, age, s.70. Hz. İsa'nın Beytlehem'de doğduğu bilgisi İncil'de mevcuttur; bkz. Luka, 2: 4-7. Ancak Ebussuûd'un Büyük İskender ile ilgili verdiği bilgi, İskender'in M.Ö. 323 yllında öldüğü dikkate alınırsa doğru olma ihtimali taşımamaktadır. Hz. Meryem'in ne zaman öldüğü konusunda ise Hıristiyan kaynaklarında bazı görüşler aktarılmakla birlikte kesin bir bilgi bulunmamaktadır; bkz. Tümer, age, s.78-79. 
Ebussuûd Efendi, Hz. İsa'ya Kur'an'da "Meryem oğlu” şeklinde hitap edilmesini dikkate alarak, neslin, kızların çocuklarını da kapsadığına delil teşkil ettiğini ifade eder. ${ }^{85}$ Diğer taraftan bu isimlendirmede, Hıristiyanların Hz. İsa hakkındaki inanışlarına bir reddiye olduğunu da belirtir. ${ }^{86}$ Diğer bir ifadeyle Hz. İsa'nın, Kur'an'da Hz. Meryem'in oğlu olarak takdim edilmesi, tevhid inancının vurgulanması açısından ehemmiyet arz etmektedir.

\section{Doğum sonrası}

Doğum gerçekleştikten sonra Hz. Meryem, kucağında çocuğuyla birlikte insanların yanına gelir. Topluluktaki insanlar onu suçlar mahiyette "Ey Meryem, sen daha önce bic görülmemis bir şey yaptın. Ey Hârûn'un ker. kardeşi! Senin baban kötü bir kimse değildi. Annen de iffetsiz değildi." (Meryem, 19/27-28) derler. İmam Mâtürîdî̀nin, âyette geçen "Hârun" ismiyle kimin kastedildiği hakkındaki görüşlerine daha önce değinmiştik. Ona göre, insanların buraya kadar söyledikleri sözler henüz açıç̧a bir zinâ iftirası içermemektedir. Onlar sadece kendi şaşkınlıklarını dile getirmektedirler. ${ }^{87}$ Bununla birlikte $\mathrm{Hz}$. Meryem, Hz. İsa'ya hamile kaldığında, insanların ona iftira attığını Kur'an-1 Kerîm "Bir de inkârlarndan ve Meryem'e büyük bir iftira atmalarmdan ... dolayn kalplerini mübürledik." (Nisâ, 4/157) âyetiyle haber vermektedir. İmam Mâtürîdî, bu atılan iftiranın ne olduğuna dair bilgiyi İbn-i Abbas'ın görüşüne dayandırır ve bunun "zina" olduğunu söyler. ${ }^{88}$ Nitekim bu görüş ona göre, "Kucağında çocuğu ile halkmmn yanma geldi. Onlar ş̈̈lle dediler: Ey Meryem! Cok çirkin bir șey yaptm?’ âyetiyle de örtüşmektedir.

Kendi halkının bu meraklı bakışları ve soruları karşısında $\mathrm{Hz}$. Meryem'in cevab1 Kur'an-1 Kerîm'de şöyle aktarılır: “Bunun üzerine (Meryem, cocukla konusun diye) ona işaret etti. "Beşikteki bir bebekle nasil konusuruz?" dediler"'(Meryem, 19/29). Bebek ise onlara şöyle cevap verdi: "Sü̈hesiz ben Allab'ın kuluyum. Bana kitabr verdi ve beni bir peygamber yaptı." (Meryem, 19/30). İmam Mâtürîdî, bu âyetin yorumunda sadece Hz.

\footnotetext{
İşâd, 6/85 (II, 244).

İşâd, 19/34 (III, 582).

Te'vilât, 19/27 (IX, 132).

88 Te'vîlât, 4/156 (IV, 100).
} 
İsâ'ya verilen kitabın ne olduğuna değinir. Ona göre, buradaki kitap, İncil ve Tevrat'tan farklı bir şekilde "kitabın bilgisi" anlamına gelmektedir. Zira başka bir âyette Allah Teâlâ "ona kitabı, hikmeti, Tevrat ve Incili ögrettî" (Âl-i İmrân, 3/48) buyurmaktadır. Dolayısıyla burada kitap İncil ve Tevrat'tan farklı bir şey olarak zikredilmiştir. ${ }^{89}$

\section{e. Hz. Meryem'e İlahlık İsnadı}

Kur'an-1 Kerîm “Allah, söyle diyecek: "Ey Meryem oğlu İsa! Sen mi insanlara, Allah'ı brrakarak beni ve anamı iki ilâh edinin, dedin?" Isa da şöyle diyecek: "Seni bütün eksikliklerden uzak tutarm..." (Mâide, 5/116) âyetiyle Hz. Meryem hakkında ilahlık iddiasında bulunulduğundan bahseder. Hıristiyan geleneğinde $\mathrm{Hz}$. Meryem teslîsin bir uknûmu sayılmadığı halde Kur'an'daki bu ifadelerin ne anlama geldiğiyle ilgili olarak bazı yorumlar yapılmıştır. Buna göre, Hz. Meryem'in Tanrı'nın annesi (Theotokos) olarak kabul edilmesi, asli günahtan korunmuşluğu (Immaculate) ve öldükten sonra oğlu gibi göğe yükseltilmesi (Assumption) gibi kilise tarafindan kabul edilen inançlara bağlı olarak halk arasında Hz. Meryem'e aşırı önem verilmesine, aynı zamanda özellikle Katolik ve Ortodoks kiliselerindeki Meryem kültüne işaret şeklinde yorumlanabilir. Bunun yanı sira Arap yarımadasında Meryem'i tanrı gibi kabul edip ona tapinan ve kendilerine Collyridien denilen bir kadınlar zümresinin, yine Tanrı, Îsâ ve Meryem'in oluşturduğu bir teslîse inanan Meryemîler'in (Mariamites) mevcudiyeti, söz konusu ayetlerin anlaşılmasında ele alınabilir. ${ }^{90}$ Dolayısıyla her ne kadar Hz. Meryem, Hıristiyanların geneli açısından resmî söylemde tanrısal üçlemenin bir parçası olarak görülmüyorsa da, pratikte kendisine yüklenen anlamlar ve görevler sebebiyle birtakım tanrısal niteliklere sahip kilınmıştır. Aslında bu durum, sahip olduğu seçkin vasıflar nedeniyle aşırı derecede önem verilip yüceltilen bütün insanlar için söz konusu olan bir tehlikedir. Özellikle bir insanı

89 Kanonik İnciller, Hz. İsa'nın henüz kundaktayken, annesine yapılan iftira sebebiyle konuşmasına dair bir olaydan bahsetmezler. Bununla birlikte apokrif İncillerde başka bağlamlarda Hz. İsa'nın bebekken konuştuğuna dair bazı bilgiler mevcuttur. Örneğin bkz. Ekrem Sarıkçıŏlu, age, s. 76-77.

90 Harman, "Meryem", XXIX, 241. Bu konuyla ilgili daha ayrıntılı bilgi için bkz. Hasan Tevfik Marulcu, "Hıristiyanların Hz. Meryem’e Tanrılık İsnadı: Müslüman Kelamı Açısından Bir Değerlendirme”, SDÜ İlabiyat Fakültesi Dergisi, sayı: 24 (2010), ss. 61-72. 
ilahlaştırmanın açıkça gerçekleştiği Hıristiyanlık gibi bir kültürde bu tür sonuçların ortaya çıkmasını beklemek hiç de zor değildir.

Nitekim Ebussuûd Efendi “...Öyleyse Allah'a ve peygamberlerine iman edin, "(Allah) üctür" demeyin..." (Nisâ, 4/171) âyetini tefsir ederken, "üç" tabirini Allah, İsa ve Meryem olarak açıllar. Ona göre yukarıda aktardığımız Mâide, 5/116 âyeti de bunu ifade etmektedir. Bununla birlikte o, bu âyette geçen "üç" tabirinin Huristiyan inançlarına uygun farklı bir yorumunu daha yapar. Şöyle ki, Hıristiyanlara göre Allah'ın tek bir cevheri, üç uknumu vardır. Bunlar da zat/vücûd olan Baba, ikincisi ilim olan Oğul, üçüncüsü ise hayat olan Ruhu'l-Kuds'tür. ${ }^{91}$ Dolayısıyla Ebussuûd Efendi, Kur'an'daki üç ilah fikrinin yorumlanmasında, mevcut durumları da göz önüne almaktadır. Bu bağlamda o, başka bir âyetin tefsirinde baz1 Hiristiyan gruplardan isimleriyle bahsetmektedir. Onun aktardığına göre, Melkânîlerin (ya da Yâkûbîlerin) "Meryem, ilah doğurdu" görüşünü ileri sürdüklerini belirtir. ${ }^{92}$ Ancak onun adı anılan bu gruplarla ilgili verdiği görüşler arasında bazı tutarsızlıklar mevcuttur. ${ }^{93}$ Dolayisiyla Hz. Meryem, teslisin bir unsuru olarak kabul edilmese de, hakkındaki bir takım inançlar, onun ilahlık konumuna yükselmesi gibi sonuçlar doğurabilmektedir. Kur'an-1 Kerîm'in bu konudaki beyanlarını bu şekilde anlamak daha doğru olacaktır. Zira Kur'an, teslisten bahsettiği yerlerde Hz. Meryem'i anmamaktadır.

İmam Mâtürîdî ise, bu âyetle ilgili olarak, Hz. Meryem hakkında mevcut Hıristiyan inançlarına herhangi bir atıfta bulunmaz. O sadece, teolojik bir yorumda bulunarak anne ve oğul olmanın ilah olmakla çelişik insanî durumlar olduğunu hatırlatır. ${ }^{94}$ Dolayısıyla onun açısından bu meselede, üzerinde durulması gereken asıl husus, Kur'an'ın beyanlarının, yaşanan sosyolojik ve tarihsel gerçekliklerin hangi boyutlarda ve

$91 \quad \dot{I} \operatorname{rşâd}_{\text {, }}$ 4/171 (I, 822).

92 İşâd, 5/72 (II, 28).

93 İrşâd, 19/35 (III, 582). Ebussuûd Efendi burada Melkânîlerin Hz. İsa'y1 Allah'in kulu ve peygamberi, Nastûrîlerin Tanrı'nın oğlu, Yâkûbîlerin ise yeryüzüne inmiş Tanrı olarak kabul ettiklerini aktarır. Adı geçen Hıristiyan gruplar, Müslümanlara ait erken dönem dinler tarihi eserlerinde sıklıkla anılmaktadır. Örneğin bkz. İbnHazm, el-Fasl, Beyrut 1996, I, 110 vd.;

94 Te'vîlât, 5/116 (IV, 376-377). 
vasıflarda cereyan ettiğini tesbit etmekten ziyade, söz konusu problemin İslam'ın temel paradigması olan tevhid açsından ele alınıp kelamî/felsefî açıdan değerlendirilmesinin yapılmasıdır. Burada dikkat edilmesi gereken hususlardan bir tanesi de, Hz. Meryem hakkındaki ilahlık düşüncelerinin reddedilmesi esnasinda, Kur'an tarafindan ortaya konan, onun üstün ahlakî nitelikleri ile örnek insan oluş durumunu zedelemeyecek bir üslubun titizlikle korunmuş olmasıdır.

\section{f. Hz. Meryem, Vahy ve Peygamberlik}

İslâm düşüncesinde kadınların peygamber olup olamayacakları meselesi tartışmalı bir husustur. Bazı İslâm âlimleri, Kur'an'da geçen beyanlar bağlamında kadınların da peygamber olabileceği kanaatindedir. Bu görüşü benimseyenler açısından Hz. Meryem en başta gelen örnek konumundadır. Ancak Mâtürîdî gelenek, genel bir kanaatle kadınların peygamber olarak görevlendirilmediklerini kabul etmektedir. ${ }^{95}$

İmam Mâtürîdî, Hz. Musa ile ilgili kıssada yer alan ve onun annesine vahyedilmesi meselesini, peygamberlik açısından değerlendirir. $\mathrm{Bu}$ mesele aynı zamanda Hz. Meryem'in durumuyla ilgili bazı benzerlikler içermektedir. Söz konusu âyet-i kerimede "Mûsần annesine, "Onu emzir, bașina bir șey gelmesinden korktuğun zaman onu denize (Nil'e) burak, korkma,

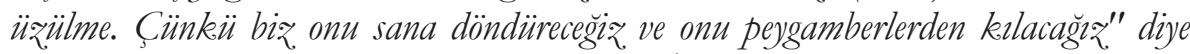
vahyettik." (Kasas, 28/7) buyrulmaktadır. İmam Mâtürîdî, çoğu müfessirin görüşünün, burada geçen "vahy" tabirinin "rasul" olmayı gerektiren, elçi olarak gönderme anlamındaki vahiy olmadığını, aksine kalbe bir bilgi yerleştirme manasındaki "ilham" olduğunu zikreder. Bununla birlikte ona göre, buradaki vahyin peygamber göndermedeki vahiy gibi olması da mümkündür. Ancak bu vahiyle kişinin rasul olması gerekmez. Görebildiğimiz kadarıyla İmam Mâtürîdî, âyette yer alan ifadelerin bir kısmının ancak sözlü olarak bildirilme yoluyla bilinebileceği fikrine

95 Örneğin Kemalpaşazâde, Eş’arî-Matürîdî ihtilafindan bahsettiği risalesinde, erkek olmanın peygamberliğin şartlarından biri olduğu görüşünü Mâtüridiyye'nin görüşü olarak zikreder (Kemalpaşazâde, "Risâle fi'l-İhtilâf beyne'l-Eşầira ve'lMâtüridiyye", Hamsu Resâil fi'l-Firak ve'l-Mezâbib, haz. Seyit Bahcivan, Kahire 2005, s. 77). Bu konuda İslam düşüncesinde ortaya çıkan fikirler hakkında daha geniş bilgi için bkz. Hüdaverdi Adam, "Nübüvvete Dair İki Mesele, Nebi ile Rasul Arasındaki Fark ve Kadının Peygamberliği”, Sakarya Üniversitesi İlahiyat Fakültesi Dergisi, 1996, say1: 1, ss. 95-105. 
istinaden, olayın belirsiz bir ilham olmasından çok, açık bir ihbar olduğu görüşünü savunmaktadır. Ancak sonuçta o da, bu durumun peygamberliği gerektirmeyeceği kanaatindedir. ${ }^{96}$ Dolayısıyla ona göre vahyin geliş biçiminin peygamberlikte olduğu gibi gerçekleşmiş olması, bu vahyi alanın peygamber olmasını gerektiren bir durum değildir. Diğer bir ifadeyle vahyin şekli bir kişinin peygamber olup olmamasını belirleyen ana unsur değildir.

Ebussuûd Efendi ise, aynı olayla ilgili olarak "Hani annene vahyedilmesi gereken șeyleri vabyetmiștik" (Tâhâ, 20/38) âyetini yorumlarken benzer ihtimalleri diler getirir. Ona göre $\mathrm{Hz}$. Musa'nın annesine iletilen vahiy, ya Hz. Meryem'e vahyettiği gibi peygamberliği içermeyecek bir şekilde melek vasitasiyladır, ya "Rabbin arya vabyetti" (Nahl, 16/68) âyetinde olduğu gibi ilham yoluyladır, ya da uykuda göstermek şeklinde cereyan etmiştir. ${ }^{97}$ Dolayssıyla Ebussuûd Efendi de, İmam Mâtürîdî gibi, Hz. Meryem'e tıpkı peygamberlere geldiği gibi vahiy gelmesi, vahiy meleğinin görünmesi, adının diğer peygamberler gibi anılmasını ${ }^{98}$, onun peygamberliği değil, Allah katında konumunun yüceliği olarak ele almaktadır. Diğer bir ifadeyle, Hz. Meryem bütün hayatı boyunca sergilediği davranışlar ve taşıdığı vasıflar itibarıyla, peygamberlere ait bazı nitelikleri üzerinde göstermiş, hatta onlara ait bazı görevleri yerine getirmiştir denilebilir. Bununla birlikte bu durum, özel bir görevlendirme olan peygamberlik olarak değerlendirmeyi zorunlu kılmaz. Belki burada şu hususu da hatırlatmak gerekir: İmam Mâtürîdî açısından, bir prensip olarak kadınların peygamber olmaması, cinsiyete bağlı bir eksiklik sebebiyle değildir. Ona göre kadınların peygamber olarak görevlendirilmemeleri, bu görevin gerektirdiği toplumsal boyutta gerçekleştirilmesi gereken bazı durumların, kadınların mahremiyetiyle uyumlu olmamasından kaynaklanmaktadır. Diğer bir ifadeyle $\mathrm{Hz}$.

\footnotetext{
Te'vîlât, 28/7 (XI, 11-12).

İşâd, 20/38 (III, 627-628).

98 Yukarıda da zikrettiğimiz gibi, Kur'an-1 Kerîm Hz. Meryem'den, peygamberleri andığı bir üslup ile bahsetmektedir. Örneğin Meryem suresinin hemen başında Hz. Zekeriyya'nın anılmasından/zikredilmesinden (19/1) bahsedilmektedir. Ardindan tamamen ayn tarzda “Kitap'ta Meryem'i de zikeret" (19/16), “Kitap'ta İbrabim'i de

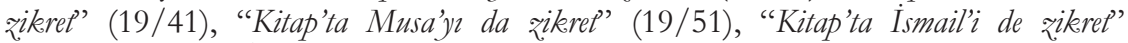
(19/54), "Kitap'ta İdris'i de zikeret” (19/56), beyanlar1 yer almaktadır.
} 
Meryem, peygamber olarak görevlendirilmemiş bile olsa, vahiy alma ve bütün hayatı boyunca üstün ahlakî vasıflarla diğer insanlara örnek olma gibi, peygamberlere mahsus olduğu düşünülen niteliklere sahip olması bakımından, Kur'an-1 Kerîm'de peygamberlere has bir üslupla tebcil edilmiştir.

\section{Değerlendirme}

İmam Mâtürî̀î ve Ebussuûd Efendi'nin tefsirlerinde $\mathrm{Hz}$. Meryem hakkındaki beyanları, tefsir ilminin temel metod ve kaynaklarını kullanmaları bakımından benzerlikler arz etmektedir. Her iki müellif de yorumda bulunurken, Kur'an-1 Kerîm'in bütünlüğüne, Hz. Peygamber (sas) ve Müslümanların ilk neslinin konuyla ilgili açıklamalarına, Arapça dilbilgisi kurallarına başvurmakta, tevhid ve nübüvvetle ilgili İslâm düşüncesinin temel ilkelerini sürekli olarak ön planda tutmaktadırlar. Buna bağlı olarak onlar Hz. Meryem'i, tarihte yaşamış başka bir dinin önemli bir karakteri olarak görmemişler, aksine bütün peygamberler gibi örneklik niteliği taşıyan müslüman bir karakter şeklinde değerlendirmişlerdir.

Bununla birlikte iki müfessirin birtakım farkl1lklar sergiledikleri de bir gerçektir. İmam Mâtürî̀î, tarihî kıssalardan bahsetmesini Kur’an-1 Kerîm'in bir mucizesi olarak görmekte ve daha önce bu konular hakkında bilgisi olmayan Hz. Muhammed (sas)'in peygamberliğinin bir delili olarak değerlendirmektedir. Bu yaklaşım tarzı onun, tarihi kıssaların açıklanmasında Ehl-i Kitap'tan gelen bilgileri kullanmasinı son derece sınırlamıştır. Ona göre bu tür bilgilerin sağlamlığ1, Kur'an ve Sünnet beyanlarının yanında oldukça şüpheli konumdadır. Sonuç olarak Te'vîlât ta tarihî olaylarla ilgili karşılaştırmalı ve tartışmalı bir üslubun minimum seviyede bulunduğunu söyleyebiliriz. $\mathrm{Bu}$ durumun oluşmasinda, İmam Mâtürî̀ı’nin içinde bulunduğu kültürel çevrede Hiristiyanlarla birlikte yaşama tecrübesinin bulunmamasının rolünü de hesaba katmak yanlış olmayacaktır. Bu durum bize, Hz. Meryem hakkındaki Kur'an beyanlarını, dinleyicileri arasında Hiristiyanların bulunmadığ1 ve onların tepkilerinin dikkate alınmadığ1 ilmî ve içtimâî bir ortamı yansitmaktadır.

Diğer taraftan Ebussuûd Efendi'nin tefsirinde, gerek Kanonik gerekse apokrif Hıristiyan kaynaklarında yer alan bazı bilgilere daha çok yer vermesi, İmam Mâtürîdî ile arasındaki önemli bir farklılık olarak dikkat çekmektedir. Her ne kadar Ebussuûd'un bu yaklaşımı kendine has 
bir tavır olmayıp, kendisinden önceki pek çok müfessir tarafindan benimsenmiş olsa da, bunun ortaya çıkmasında kültürel çevre ve şartlanın da etkili olduğunu düşünmek mümkün görünmektedir. Zira bilindiği üzere, Ebussuûd Efendi, ciddi bir Hiristiyan tebaası olan büyük bir devletin en üst düzeyde dinî görevlisi olarak çalışmıştır. Bu konum, onun hayatında pek çok kere Hıristiyanlarla temasta olmasına imkân vermiştir.

Ancak burada hatırlatmamız gereken bir husus daha vardır. Her ne kadar Ebussuûd Efendi'nin tefsirinde Hiristiyan kaynaklarla uyumlu bir takım bilgilerin varlığından bahsedebilirsek de, bunların bizzat onun tarafından söz konusu kaynaklardan elde edildiğini söylemek kolay değildir. Bunu, iki temel nedene dayanarak ifade ediyoruz. Bunlardan ilki, söz konusu bilgiler, Ebussuûd'un kaynakları arasında bulunan daha önceki tefsirlerde de yer almaktadır. İkinci husus ise, bu bilgilerin büyük ölçüde İslâm'ın temel kabullerine göre yeniden düzenlenerek, deyim yerindeyse islamîleştirilmeleridir. Örneğin Hz. İsa'nın çarmıh hadisesinden sonra $\mathrm{Hz}$. Meryem tarafından görülmesi, Hıristiyan kaynaklarında aktarılan bilgilere önemli ölçüde uygunsa da, bu esnada Hz. İsa'dan aktarılan "Rabbim beni yükseltti ve bana hayırdan başka bir şey isabet ettirmedi. Bu ise (çarmı) onlara öyle göründü” sözü, meselenin İslâmî tarafinı yansıtmaktadır. Yine benzer bir şekilde, Hz. İsa'nın doğumundan sonra nerede bulundukları ile ilgili Kur'an-1 Kerîm'de açık bir bilgi bulunmaması, Hz. Meryem'in nişanlısı Yusuf ile ilgili hiçbir beyanın bulunmaması, İrşâd da da bu alanların suskun geçilmesinde etkili olmuş olmalıdır. Bununla birlikte Kur'an'ın dikkatlere sunduğu Hz. Meryem'in hayatına dair daha ayrintılı bilgi elde etme isteğinin bu tefsirde kendisini izhar ettiğini söyleyebiliriz. Bu tavır, İmam Mâtürî̀î̀nin endişeleri açısından değerlendirildiğinde, çok da sakıncalı görülmemiş olmalıdır. Zira zaten istifade edilen bilgiler Ehl-i Kitab'ın elinde bulunan bilgilerden gelmekte ve dolayısıyla çelişme ihtimali olan tarihi gerçekleri söz konusu anlatılar meydana getirmektedir. Ancak burada dikkat edilmesi gereken asıl husus, Kur'an'in, Hz. İsa ve Hz. Meryem ile ilgili Hiristiyanlar tarafindan kabul edilen ve inanç haline dönüştürülen birçok hususu reddediyor olmasıdır. O halde yapılması gereken, bu tür anlatıları belli bir süzgeçten geçirerek almaktır.

Diğer taraftan, Ebussuûd Efendi’nin, tefsir metodu açısından İmam Mâtürîdî'den farklılaştığı yerlerde Zemahşerî ve Fahreddin Râzî gibi farklı itikâdî ekollere mensup müfessirlerden istifade ettiğine şahit 
olmakla birlikte, kadınların peygamberliği ve keramet gibi, Kelâm ilmini ilgilendiren tartışmalı meselelerde İmam Mâtürî̀î̀nin çizgisinden ayrılmadığını da görmekteyiz. Bu da, bizim onu Mâtürîdî müfessirler arasında görme gerekçelerimizden birisidir. Diğer bir açıdan, Kur'an'da yer alan tarihî kıssalar, geçmişe ait bir malumat yığını olmanın çok ötesinde, Kelam ve F1kıh gibi dinin farklı disiplinleri bakımından delil olma vasfinı taşımaktadırlar.

Hz. Meryem, hem Hiristiyan hem de İslâm dünyası açısından günümüzde de rol model olmaya, gerçek öyküsü üzerinden insanllğa hizmet etmeye devam etmektedir. Dinî kaynakların üstün ahlakî nitelikler atfederek bahsettiği ve öne çıkardığı bu saygıdeğer karakterin anlaşılması ve anlatılmasinda mevcut imkânların seferber edilmesi, günümüz dünyasının dinî yapısı açısından son derece ehemmiyet arz etmektedir. Farklı kültürler arasındaki iletişim imkân ve şartlarının büyük ölçüde değiştiği çağımızda bu misyonun daha elzem ve nispeten daha kolay olduğunu düşünüyoruz. Dünyanın yarısından çoğuna yayılmış iki dinin ortak mirası olan Hz. Meryem'in daha iyi tanınmasının, gittikçe sekülerleşen ve bundan dolayı da artan bir şekilde ahlakî anlamda hastalanan bireysel ve toplumsal yaşantımızın manevî cephesine şifa olacağını varsaymak hiç de zor değildir. Ele aldığımız iki tefsirin, Kur'an beyanlarını açıklamada bazı farklı yaklaşımları söz konusu olsa da, İslam dininin tevhid ve ahlak alanındaki temel prensiplerini doğru yansıttı̆̆1 müddetçe, kısıtlamaların azaltılarak kaynakların daha verimli kullanılması anlayışının önünü açtıklarını düşünüyoruz. Kendi dönemleri ve şartları itibarıla bunu en iyi şekilde sergilemeye çalışan bu iki tefsir, karşılaştırmalı çalışmalar yapma hususunda teşvik edici bir rolü de yerine getirmektedirler. Bu tavır, aynı zamanda sadece iki dinin değil, bir bütün olarak insanlık tarihinin en önemli karakterlerinden birinin, kısıtlamalardan kurtarılarak evrensel bir değer oluşunun anlaşılmasında daha etkili olacaktır. Belki de Kur'an-1 Kerîm'in, tarihteki kahramanları görmezden gelerek, yeni kahramanlar ortaya çıkarma yaklaşımı yerine, onları ortak değerler olarak kabul edip bir kere daha yüceltmesini bu açıdan okumak mümkündür. 


\section{KAYNAKÇA}

Adam, Hüdaverdi, "Nübüvvete Dair İki Mesele, Nebi ile Rasul Arasındaki Fark ve Kadının Peygamberliği”, Sakarya Üniversitesi İlabiyat Fakültesi Dergisi, 1996, say1: 1, ss. 95-105.

Ahmed b. Hanbel, Müsned, tah. Şuayb el-Arnavud, Müessesetü’r-Risale, 1999.

Aydemir, Abdullah, Ebussund Efendi ve Tefsirdeki Metodu, Ankara 1969.

Aydemir, Abdullah, Tefsirde Issailiyyat, İstanbul 1992.

Aziz S. Atiya, Doğu Hıristiyanlı̆̆ Taribi, çev. Nurettin Hiçyllmaz, İstanbul 2005.

Bedir, Ahmed, “Kur'an ve İncillere Göre Hz. İsa'nın Var Olduğu İleri Sürülen Kardeşleri Meselesi”, Harran Üniversitesi İlabiyat Fakültesi Dergisi, IV (1998), ss. 124-129.

Buhârî, el-Câmiu's-Sahih, tah. Muhammed Zehîr b. Nâsır, Dâru Tavki'nNecât, 1422.

Cerrahoğlu, İsmail, "Ebus-Suûd ve Tefsiri", Diyanet İsleri Başkanliğr Dergisi, c. XIII, s. 4, ss. 195-203.

Düzdağ, Ertuğrul, Ebussund Efendi Fetvalar, İstanbul 1983.

Ebussuûd, İrşâdu Akli's-Selìm ilâ Mezâya'l-Kitâbi'l-Kerîm, tah. Abdülkâdir Ahmed 'Atâ, Riyâd 1971.

Emmerich, Anne Cathrine, Life of Blessed Virgin Mary, trans., Sir Michael Palairet, Cambridge 1953.

Foster, Paul, The Non-Canonical Gospels, London 2008.

Galli, Ahmed, "Mâtürîdî Tefsirinin Bazı Yönleri”, DEÜ İlabiyat Fakülttesi Dergisi, s. 4, ss. 467-480.

Hâkim en-Nîsâbûrî, el-Müstedrek ale's-Sabihayn, Dâru'l-Kutubi'l-İlmiyye, Beyrut 1990.

Harman, Ömer Faruk, "Meryem”, DIA, XXIX, ss. 236-242.

İbn Hazm, el-Fasl, Beyrut 1996. 
Kemalpaşazâde, "Risâle fi'l-İhtilâf beyne'l-Eşâ’ira ve'l-Mâtüridiyye", Hamsu Resâil fi'l-Firak ve'l-Mezâhib, haz. Seyit Bahcivan, Kahire 2005.

Kermeli, Eugina, 'Ebu's-Su'ûd'a Göre Kilise Vakıfları ve Osmanlı Hukukundaki Teori ve Pratiği", çev. Özgen Özcan, Vakıflar Dergisi, say1: 34 (2010), ss. 165-175.

Marulcu, Hasan Tevfik, "Hıristiyanların Hz. Meryem'e Tanrılık İsnadı: Müslüman Kelamı Açısından Bir Değerlendirme”, SDÜ İlabiyat Fakültesi Dergisi, say1: 24 (2010), ss. 61-72.

Mâtürîdî, Ebû Mansur, Te'vîlâtui'l-Kur'an, tah. Ahmed Vanlığlu, İstanbul 2005.

Müslim, el-Câmin's-Sahih, Dâru'l-Cîl, Beyrut trs.

Placher, W.C., A History of Christian Theology, Philadelphia 1983.

Rogers, Adrian "A Portrait of Christ", http://www.oneplace.com/ministries/love-worthfinding/read/articles/a-portrait-of-christ-10200.html (20.10.2015).

Sarıkçığlu, Ekrem, Diğer Inciller (Apokrif Inciller), Isparta 2005.

Tirmizî, Sünen, Dâru’l-Cîl, Beyrut 1998

Tümer, Günay, Hiristiyanllkta ve İslâmda Hz: Meryem, Ankara 1996.

Uludağ, Süleyman, “Keramet”, DİA, XXV, 265-268.

Zemahșerî, el-Keșsâf, tah. Șeyh Âdil Ahmed Abdülmevcud, Riyad 1998.

Zeylaî, Cemalüddin, Tabricu'l-Ehâdîs, Riyad 1414. 